\title{
A DERROTA DE TASSO JEREISSATI NA DISPUTA PARA O SENADO EM 2010: COMO ENTENDER A DISSOLUÇÃO DE SUAS BASES ELEITORAIS?
}

\author{
Rejane Maria Vasconcelos Accioly de Carvalho \\ Jakson Alves de Aquino
}

\begin{abstract}
Resumo
Neste artigo, revisamos a cobertura política realizada pela imprensa local e analisamos os resultados eleitorais e os dados de survey pós-eleitoral realizado no estado do Ceará sob nossa coordenação para analisar a rápida dissolução das supostamente sólidas bases eleitorais de Tasso Jereissati, o qual dominou a política cearense por duas décadas. O caso das eleições de 2010 no Ceará indica que nas eleições para o governo estadual e para o Senado os eleitores tendem a votar nos candidatos que são percebidos como estando no mesmo lado político: situação ou oposição. A tendência das lideranças é movimentar-se em direção ao polo situacionista, e somente tomar decisão diferente em campanhas cuja competitividade sugira o declínio do domínio político de determinado grupo ou partido político e a ascensão de outras forças políticas.
\end{abstract}

Palavras-chave: Tasso Jereissati; Bases Eleitorais; Eleições; Cultura Política; Poder Político.

\begin{abstract}
In this paper, we review the press coverage of politics and analyze the election results and the data from post-election survey that we conducted in the State of Ceará to explain why the supposedly solid Tasso Jereissati's electoral bases quickly dissolved after two decades of political domain. The case of Ceará in the 2010 elections indicates that voters, when voting to governor and senator, tend to choose candidates who are perceived as being in the same political side: government or opposition. The tendency of political leaders is to ally with the government and either remain at or go to the opposition only in campaigns whose competitiveness suggest the decline of the political dominance of a particular group or political party and the rise of other political forces.
\end{abstract}

Keywords: Tasso Jereissati; Electoral Bases; Elections; Political Culture; Political Power.

\section{Introdução}

O objetivo central deste artigo é analisar a rápida dissolução das supostamente sólidas bases eleitorais de Tasso Jereissati, o qual dominou a política cearense por duas décadas. Candidato à reeleição ao Senado em 2010, sua vitória era considerada certa até pelos opositores, que admitiam 


\section{DOSSIÊ OPINIÃO PÚBLICA, ELEIÇÕES E PARTICIPAÇÃO POLÍTICA NAS DEMOCRACIAS CONTEMPORÂNEAS}

disputar apenas uma das duas vagas a serem preenchidas. Em partidos diferentes, Tasso (PSDB) e o governador Cid Ferreira Gomes (PSB) mantinham no plano da política local a cômoda posição de aliados, até que a intervenção vinda do alto (leia-se Planalto, direção nacional do PT) impôs um divórcio que a rigor não era desejado por nenhuma das partes. O PSDB tassista, apenas no último prazo das convenções, improvisou o lançamento de candidatura própria ao governo: Marcos Cals, que insolitamente fora secretário de Justiça de Cid Gomes até afastar-se do cargo com a pretensão de mais uma tranquila reeleição para deputado estadual.

Em pesquisas eleitorais divulgadas até três semanas antes das eleições, Tasso aparecia como primeiro colocado com vasta dianteira sobre os demais concorrentes. Considerando a expectativa de que a reeleição de Tasso seria garantida pelos votos do interior, justifica-se nosso interesse em analisar como os eleitores decidiram seus votos para as eleições ao Senado de modo a promover a vitória dos dois candidatos situacionistas. Os resultados das eleições indicam que bases eleitorais fundadas em termos de lealdades tradicionais já não funcionam de modo a garantir a vitória em campanhas majoritárias.

Como os eleitores decidem o voto para o Senado de modo especial quando existe a possibilidade da escolha de dois candidatos? A tendência é seguir os candidatos apoiados pelo candidato a governador com maiores chances de vitória? Os dados gerais das eleições estaduais para o governo e Senado, que serão analisados na seção 5 sugerem a hipótese de "voto casado". Ou seja, o governador vitorioso quase sempre elege com ele os candidatos ao Senado.

André Borges nos oferece um caminho promissor para o entendimento dos processos de ascensão e declínio de grupos políticos e ou partidários no controle das máquinas políticas estaduais ao levantar a hipótese de que no Brasil "a competição vertical entre o governo federal e estadual na oferta de políticas sociais atua no sentido de constranger as estratégias da patronagem e controle da arena eleitoral dos chefes políticos estaduais" (BORGES, 2010, p. 167). Os efeitos dessa competição seriam mais fortes nos Estados mais pobres e, portanto, mais dependentes de repasses de recursos federais a serem aplicados em sua esfera de domínio político. A tendência de estabelecer uma coalizão com os partidos dominantes na esfera federal seria, assim, vital para a conquista e a longevidade do domínio da política estadual. Borges sustenta essa hipótese com dados sobre vitórias eleitorais de coalizões de esquerda em eleições estaduais no período 2002 e 2006 que acompanharam o declínio de poder dos antigos chefes políticos.

O aprofundamento da análise é feito com o estudo de caso da ascensão e declínio do domínio hegemônico de Antônio Carlos Magalhães (ACM) e do grupo carlista na política baiana no período de 1982 a 2006. Embora a referência maior seja a uma liderança pessoal, o autor ancora a análise na filiação partidária de $\mathrm{ACM}$ ao $\mathrm{PFL}$, que integrava a coalizão de 
centro direita (PFL/PMDB/PSDB) vencedora dos pleitos presidenciais do mesmo período. Seu declínio, que teve início com o rompimento com o governo FHC, de quem esperava apoio político no episódio do "escândalo" da fraude no painel de votação do Senado em 2001, acentuou-se a partir da vitória de Lula para a Presidência da República em 2002. Fora da coalizão presidencial, a decadência do grupo carlista culminou com a derrota eleitoral de seu candidato ao governo do estado em 2006 para o candidato do PT, Jaques Wagner, que encabeçava a chapa da ampla aliança partidária que replicava a base de apoio do presidente Lula.

Diferentemente do que aconteceu na Bahia, a vitória de Tasso Jereissati pelo PMDB ao governo do Ceará em 1986 apresentava-se como a derrota das chamadas elites oligárquicas, cuja força residiria no controle da máquina política estadual por "chefes políticos", leia-se coronéis Virgílio, Adauto Bezerra e César Cals, que governaram o estado durante o longo período militar (CARVALHO, 1999). A hegemonia do "tassismo" na política cearense com duração de duas décadas ocorreu na fase da redemocratização, e a transição para outro ciclo político no qual Tasso e o PSDB caem em desgraça não nos parece ser traduzível em termos de embates ideológicos entre esquerda e direita. Como argumentam Carneiro e Almeida (2008), embora os subsistemas estaduais e municipais não tenham um funcionamento independente das eleições federais (p. 426), as regras eleitorais brasileiras facultam aos dirigentes políticos estaduais "uma significativa capacidade decisória nas instâncias nacionais e muita autonomia para definir sobre candidatos e coligações nos pleitos disputados em seu âmbito próprio de atuação" (p. 410). Em muitas eleições, não são os partidos nacionais, mas as lideranças estaduais que estão no controle das disputas majoritárias (MELO, 2010).

A eleição de Cid Gomes do PSB para o governo do Ceará em 2006 sustentou-se em ampla coalizão partidária que incluiu não apenas partidos considerados de esquerda (caso do PMDB), mas o apoio eleitoral explícito do então senador Tasso Jereissati, em detrimento da candidatura à reeleição de Lúcio Alcântara do seu próprio partido, o PSDB ${ }^{1}$.

Até 2010, o senador Tasso Jereissati, embora se constituísse em uma das lideranças mais expressivas do maior partido de oposição ao Governo Federal no Senado, o PSDB, mantinha-se no plano estadual aliado aos Ferreira Gomes, integrantes da base eleitoral do presidente Lula. Quais impasses presentes na disputa para o senado em 2010 implicaram no rompimento de uma aliança que redundou na derrota de Tasso e no fraco desempenho eleitoral dos candidatos do PSDB no Ceará?

\footnotetext{
${ }^{1}$ Ver textos de autoria de Rejane Vasconcelos Carvalho sobre as eleições estaduais cearenses em 2002 e 2006 citados na bibliografia deste artigo (R. CARVALHO, 1991, 2001, 2002, 2003, 2004, 2009).
} 


\section{DOSSIÊ OPINIÃO PÚBLICA, ELEIÇÕES E PARTICIPAÇÃO POLÍTICA NAS DEMOCRACIAS CONTEMPORÂNEAS}

Consideramos que há lacunas teóricas e empíricas na compreensão de novas formas de conexão eleitoral estabelecidas entre as instâncias governamentais e as chamadas "bases eleitorais" na produção de vitórias que garantem a continuidade de ciclos políticos sob a dominância de determinadas personalidades e/ou partidos políticos ou, ao contrário, de derrotas que implicam em alternância política. A análise desenvolvida neste texto, focada na derrota de Tasso para ocupar uma das vagas para o Senado, tem a pretensão de contribuir para o debate sobre a temática das conexões eleitorais entre as diferentes instâncias do poder nacional, estadual e municipal, definidoras da dinâmica política brasileira pós redemocratização.

Utilizamos as seguintes fontes de dados: 1) cobertura política do jornal O Povo, objetivando delinear o contexto geral da campanha estadual de 2010 no Ceará, destacando informações que esclarecem o papel da disputa ao Senado na reconfiguração do campo da política estadual; 2) dados das pesquisas dos institutos IBOPE e Datafolha publicados no jornal O Povo, que sugeriam como certa a vitória de Tasso Jereissati; 3 ) resultados eleitorais divulgados pelo TRE-CE; 4) dados do survey pós-eleitoral realizado no estado do Ceará sob nossa coordenação.

\section{Tasso e os Ferreira Gomes}

A disputa das duas vagas ao Senado em 2010 marca o desfecho da aliança entre Tasso Jereissati e os Ferreira Gomes que teve início no primeiro governo de Tasso Jereissati em 1986, quando o então jovem deputado estadual Ciro Ferreira Gomes destacou-se na defesa entusiasta dos feitos do governador recém eleito que afetavam o padrão de relações até então mantido com os deputados e chefes políticos do interior classificado como clientelista. Credenciou-se assim para ocupar o posto de representante do governo na Assembleia Estadual. Em 1988, Ciro Gomes foi o nome indicado por Tasso para concorrer pelo PMDB à prefeitura de Fortaleza. O contexto eleitoral em Fortaleza era de desencanto com a gestão da prefeita Maria Luíza Fontenelle, eleita pelo PT em 1985, expulsa do partido em 1987 por denúncias de apoio informal à candidatura do coronel Adauto Bezerra, do PDS, em 1986.

Em disputa acirrada, Ciro elegeu-se prefeito por uma margem mínima de diferença de votos $(0,1 \%)$ sobre o segundo colocado, Edson Silva, radialista, candidato do PDT, considerado um "azarão" que em uma campanha com poucos recursos conseguiu a adesão de muitos eleitores à sua imagem de defensor dos pobres construída como locutor de um programa radiofônico do gênero "prestação de serviços".

Aquela foi a única vitória alcançada por um candidato apoiado por Tasso para a prefeitura de Fortaleza. Com o afastamento de Ciro Gomes da prefeitura para candidatar-se ao governo do estado em 1990, o vice empossado, Juraci Magalhães, do PMDB, impôs sua hegemonia na capital com sucessivas vitórias: em 1992, elegeu com facilidade seu candidato, Antônio 
Cambraia e em 1990 conquistou nas urnas o seu segundo mandato de prefeito, reelegendo-se na campanha de 2000.

Entretanto, nas disputas para o Governo do estado, era inquestionável a hegemonia do tassismo: em 1990, Ciro Gomes elegeu-se governador com ampla maioria de votos; em 1994, Tasso, já no PSDB, voltou ao governo com vitória em $1^{\circ}$ turno, sendo reeleito em 1998 também em $1^{\circ}$ turno.

Em 2002, Tasso elegeu seu sucessor, Lúcio Alcântara (PSDB), desta feita em uma campanha competitiva decidida em segundo turno contra $O$ candidato do PT (coligado ao PCB, PC do B, PL e PMN), um político de pouca expressão na política estadual, José Airton, ex-prefeito de Icapuí e exvereador de Fortaleza. Apesar da vitória, havia sinais do declínio da Era Tasso. O governo de Lúcio Alcântara pode ser considerado de transição do tassismo para outro ciclo político, que se tornou explícito na campanha de 2006, quando, candidato à reeleição, o governador foi derrotado por Cid Gomes do PSB em coligação com o PT, o PMDB e o PC do B. Aparentemente, Tasso saíra vitorioso daquele pleito. Afinal, o governador eleito Cid Gomes teve seu apoio informal; ele próprio elegeu-se para o Senado com expressiva votação, a segunda vaga ao Senado foi ocupada por candidata (PDT) por ele indicada, Patrícia Saboya (ex-mulher de Ciro Gomes), e Ciro Gomes (PSB), com seu apoio, foi o candidato a deputado federal mais votado no estado.

Para entender as especificidades dessa transição, é necessário reportar-se às relações políticas estabelecidas entre Tasso e os irmãos Ciro e Cid Ferreira Gomes.

Ciro construiu uma imagem pessoal com brilho próprio mantendo, porém, o cuidado de não entrar em rota de colisão com aquele que reconhecia como líder maior na política do Ceará, Tasso Jereissati. O que tornou isto possível foi a opção de Ciro Gomes de direcionar sua carreira política para o plano das disputas nacionais, o que the garantia, no âmbito da política estadual, preservar ligações pessoais e políticas com Tasso para além das filiações partidárias. Ciro Gomes saiu do PSDB em 1997, filiando-se ao PPS, para no ano seguinte candidatar-se à Presidência da República. Em 2002, ainda filiado ao PPS, candidatou-se pela segunda vez à Presidência da República e Tasso Jereissati, mesmo sendo membro da direção nacional do PSDB, declarou publicamente apoio à sua candidatura em detrimento da candidatura de José Serra (LEMENHE, 2006).

Derrotado no primeiro turno em 2002, porém detentor de uma votação expressiva, concentrada no Ceará, Ciro aliou-se no segundo turno à candidatura vitoriosa de Lula. Na primeira gestão de Lula, ocupou a direção do recém criado Ministério da Integração Nacional. Em 2006, já filiado ao PSB, partido integrante da coligação que reelegeu Lula, Ciro foi o deputado federal mais votado no Ceará e, em termos proporcionais, em todo país.

A carreira política de Cid Ferreira Gomes, inicialmente atrelada ao prestígio político de Tasso e do irmão Ciro, seguiu um curso de autonomia 


\section{DOSSIÊ OPINIÃO PÚBLICA, ELEIÇÕES E PARTICIPAÇÃO POLÍTICA NAS DEMOCRACIAS CONTEMPORÂNEAS}

progressiva na medida em que ele buscou aprofundar bases eleitorais próprias na política estadual.

Em 1990, elegeu-se deputado estadual (PSDB), sendo reeleito em 1994 (PSDB). Antes do término do segundo mandato como deputado estadual, tendo exercido a Presidência da Assembleia Legislativa, posição favorável à ampliação do seu capital político, decidiu retornar ao seu município de origem, Sobral, um dos mais populosos do estado, para candidatar-se a prefeito. Elegeu-se em 1996 e reelegeu-se em 2000 com votações expressivas (mais de $60 \%$ dos votos válidos). Na Prefeitura de Sobral, Cid deu início a uma aproximação com o PT, partido com o qual se coligou nas campanhas de 1996 e de 2000 e que ocupou a vice-Prefeitura e importantes secretarias municipais.

Vale ressaltar que Cid Gomes consolidou como prefeito de Sobral a imagem de "construtor de um Sobral novo" que recuperava o prestígio que o município tivera na história política estadual até meados do século passado. Porém, a imagem de gestor competente somente ganhou notoriedade em âmbito estadual ao ter seus feitos exibidos na TV em campanhas do PSDB para a Prefeitura de Fortaleza, como exemplo de administração a ser seguido na capital.

O terreno estava preparado para sua candidatura ao Governo do Estado em 2006 pelo PSB em uma ampla coligação partidária que reproduzia a base de apoio à reeleição de Lula (PSB, PT, PCdoB, PMDB, PRB, PP, PHS, PMN, PV). Sem dúvida, o apoio de Tasso foi importante para a vitória de Cid Gomes em 2006, conquistada em 10 turno sobre Lúcio Alcântara, candidato à reeleição pelo PSDB, entretanto, não o colocava em uma situação tributária do prestígio de Tasso. A partir daquele momento, inverteram-se as posições de poder entre eles.

Em 2008, o governador e seu partido, o PSB, integraram a coligação que reelegeu Luizianne Lins para a Prefeitura de Fortaleza e que tinha como uma das fortes adversárias a então senadora Patrícia Saboya (PDT), exesposa de Ciro Gomes, que apoiou e participou ativamente de sua campanha. O PSDB deixou de lançar candidato próprio à Prefeitura de Fortaleza, optando por apoiar a candidata do PDT. A decisão estratégica do governador Cid Gomes de manter-se em lado oposto ao de Tasso e Ciro, na disputa pela Prefeitura de Fortaleza, era um indicativo claro de que ele buscava firmar uma imagem de autonomia em relação ao tassismo.

As tensões entre os irmãos Ferreira Gomes e o então senador Tasso Jereissati apenas se tornaram explícitas nas eleições de 2010 , conduzindo ao inevitável rompimento que analisaremos mais detidamente na seção seguinte.

\section{O Cenário da disputa para o Senado em 2010}

Prenunciava-se na fase da pré-campanha o dilema que o PSDB enfrentaria durante todo o período pré-eleitoral: lançar candidato próprio ao 
Governo ou manter-se na confortável posição de apoiar e ser apoiado pelo governador em sua pretensão maior, a reeleição de Tasso Jereissati ao Senado.

Para o PSDB de Tasso, o melhor dos mundos seria receber o apoio do governador para uma das vagas do Senado e apoiá-lo na campanha de reeleição.

O acordo, firmado na campanha estadual de 2006 entre o PSB de Cid, - PT e o PMDB, envolveu a desistência de Eunício Oliveira (PMDB) de candidatar-se ao Senado, em favor do candidato do PC do B, Inácio Arruda, tendo com contrapartida a garantia de apoio à sua candidatura ao mesmo posto em 2010. Por sua vez, Tasso, que informalmente apoiou a candidatura de Cid Gomes em 2006, mantendo seu grupo político na base governista durante toda sua gestão, contava obter em 2010 o apoio do governador à sua reeleição ao Senado, considerando que havia duas vagas a serem preenchidas. Cid Gomes supostamente poderia manter o compromisso com Eunício Oliveira e ao mesmo tempo apoiar o amigo e aliado Tasso, desde que a coligação situacionista não lançasse um segundo candidato para o Senado.

Não havia no horizonte do PSDB a perspectiva de rompimento com o governador. É o que sugere o pronunciamento do presidente estadual do partido, Marco Penaforte:

Marco Penaforte, presidente estadual dos tucanos [...] diz que a candidatura de Tasso ao senado é a única alternativa para unificar o partido. Ele insiste na candidatura do maior cacique dos tucanos no Ceará. Todos concordam com essa posição. Há uma máquina disposta a entrar em campo e fazer campanha. Em segundo lugar, cogita-se candidatura própria com outro nome. O apoio a Pessoa fica em terceiro plano (O POVO, 12 jan. 2010).

Outro fator complicador das relações entre Tasso e os irmãos Ferreira Gomes era a pretensão de Ciro de candidatar-se pelo PSB à Presidência da República.

A tese por ele defendida, de que seria importante para garantir um segundo turno que o presidente Lula tivesse mais de um candidato de partidos de sua base aliada, não vingou porque, ao que parece, só interessava ao próprio Ciro. Com uma popularidade acima de $70 \%$, o presidente optou por indicar sua própria e única candidata, Dilma Rousseff, nome até então pouco conhecido na política nacional. O PSB, por sua vez, sob o comando nacional do pernambucano Eduardo Campos e o estadual presidido por Sérgio Novais, emitia claros sinais de que a candidatura de Ciro Gomes à Presidência não estava em seus planos. Os ressentimentos de Ciro transformaram-se no decorrer dos meses de fevereiro, março e abril em críticas e ofensas endereçadas ao PT, ao PMDB e ao seu próprio partido, publicadas em páginas do jornal O Povo: 


\section{DOSSIÊ OPINIÃO PÚBLICA, ELEIÇÕES E PARTICIPAÇÃO POLÍTICA NAS DEMOCRACIAS CONTEMPORÂNEAS}

Ciro, que ontem encontrou-se com o presidente nacional do PSB, o governador de Pernambuco, Eduardo Campos, voltou a atacar o PT. Ele acusou a legenda de tratar os aliados nãofisiológicos como "bucha de canhão" e "chiqueiro de ovelha" $(6 / 2 / 2010)$.

Tal situação repercutia na disputa para o Senado com declarações do governador de que sua tomada de posição em relação às candidaturas ao Senado dependia da definição do quadro da sucessão presidencial.

O PT colocava o governador em situação melindrosa ao exigir dele o apoio à candidatura de Dilma Rousseff e às duas candidaturas da coligação ao Senado, Eunício Oliveira e José Pimentel.

A prefeita Luizianne Lins já disse que o PT terá candidato próprio ao Governo do Estado, caso Ciro concorra à sucessão de Lula. Tudo para garantir um palanque forte para a ministra-chefe da Casa Civil, Dilma Rousseff (O POVO, 6/2/2010).

A ameaça era mais um ingrediente de uma encenação na qual o PT sabia que não tinha em suas fileiras um nome com densidade política para fazer frente ao governador Cid Gomes, e este, por sua vez, reconhecia que era fundamental para ele manter e, se possível, ampliar a coligação que o elegera em 2006.

A estratégia adotada por Cid foi adiar ao máximo a divulgação de suas decisões, deixando que o tempo e a força das circunstâncias conduzissem a um desfecho já esperado, mas no qual ele não aparecia como autor material do gesto de rompimento com Tasso Jereissati.

Matéria publicada em $1^{\circ}$ de maio de 2010, sob o título, O Governador quer, tucanos também, mas resistência persiste, reporta-se a um "casamento" desejado pelas duas partes, mas que encontrava impedimento por uma terceira, o PT:

O dilema político vivido pelo governador Cid Gomes (PSB), que vem sendo pressionado por PT e PSDB a optar entre uma das siglas no palanque, é a prova de que, também na política, não se pode ter tudo. Abrir mão de aliados, cargos e até da própria ideologia faz parte do jogo. É o custo das alianças. E paga quem quer (O POVO, 1/5/2010).

Na mesma matéria, o registro de que o presidente municipal do PSB, Sérgio Novais, tinha previsto este impasse com Cid ainda em 2007, quando a sigla tucana foi chamada a compor o primeiro escalão do Governo:

Integrante da "ala histórica" do PSB e mais próxima de legendas como PT, PC do B e PDT, Novais foi contra a 
incorporação peessedebista, argumentando que não havia afinidade ideológica entre os dois partidos: "Politicamente, confunde, deseduca o eleitor".

O anúncio da decisão oficial do PSB sobre a exclusão de Ciro Gomes da disputa presidencial aconteceu após reunião da executiva nacional do partido realizada em Brasília em 27 de abril, na qual a maioria absoluta dos dirigentes do partido, incluindo Sergio Novais, do Ceará, votou contra a tese de candidatura própria do partido à Presidência da República.

O PSDB insistia em apostar que os ressentimentos resultantes do não lançamento de Ciro como candidato a presidente pelo PSB poderia abalar as relações do governador e de seu irmão com o PT, favorecendo o apoio à candidatura de Tasso Jereissati. Após uma desgastante espera por uma negociação política com Cid Gomes, que se estendeu quase ao limite legal para realização das convenções do partido, Tasso manifestou publicamente sua insatisfação com o tratamento a ele dispensado pelo até então aliado.

A matéria intitulada "Tasso teme estar sendo cozinhado por Cid e convoca reunião para decidir rumos eleitorais" (O POVO, 8/6/2010) é reveladora de que a esperança de contar com a adesão do governador se esgotara.

O senador Tasso Jereissati avisou ontem que o prazo para o PSDB definir suas estratégias eleitorais se encerra neste final de semana. Num gesto de pressão contra o governador Tasso afirmou que "tendo ou não conversa com Cid, o PSDB vai fechar suas definições eleitorais até a próxima sexta feira" (O POVO, 8/6/2010).

Três dias após, o desfecho ganhou manchete: De aliado a adversário Sem resposta de Cid, PSDB anuncia disputa ao governo (O POVO, $11 / 6 / 2010)$.

O presidente estadual do partido, Marco Penaforte, explica que

a reação é resultado de uma série de desgastes com o Palácio Iracema. Ele disse que o insistente silêncio de Cid sobre as coligações para a corrida eleitoral deste ano soou como ingratidão diante da fidelidade da sigla (O POVO, 11/6/2010).

A primeira evidência de que o PSDB não tinha um plano alternativo ao rompimento da aliança com Cid Gomes é que somente às vésperas da convenção foi "inventada" a candidatura do deputado estadual Marcos Cals ao Governo do estado. A segunda é Tasso não ter indicado ou firmado acordo com nenhum outro candidato ao Senado com quem poderia fazer "dobradinha" para a segunda vaga.

Com a realização das convenções estaduais dos partidos ao final de 


\section{DOSSIÊ OPINIÃO PÚBLICA, ELEIÇÕES E PARTICIPAÇÃO POLÍTICA NAS DEMOCRACIAS CONTEMPORÂNEAS}

junho, definiram-se as chapas das três coligações principais para as disputas para o Governo e o Senado:

Coligação Por um Ceará Melhor para Todos (integrada pelos partidos PSB, PT, PMDB, PC do B, PDT, PSC e PC do B) com o nome do governador Cid Ferreira Gomes como candidato à reeleição, tendo como vice o deputado estadual e presidente da Assembleia Legislativa Domingos Filho do PMDB. Para o Senado, venceu a tese defendida pelo PT de ter dois candidatos da coligação ao Senado: Eunício Oliveira (PMDB) e José Pimentel (PT).

Coligação Por um Ceará Moderno e Forte, integrada pelos partidos de oposição PSDB e DEM, lançou a candidatura do deputado estadual Marcos Cals para o governo, tendo como vice o empresário Pedro Fiúza. Para o Senado, Tasso Jereissati era candidato à reeleição.

Coligação Para fazer brilhar o Ceará integrada pelos partidos PR, e PPS apresentou o ex governador Lúcio Alcântara (PR) para concorrer ao Governo e o empresário Alexandre Pereira (PR) para o Senado.

Os partidos minoritários lançaram candidatos próprios para o Senado, elevando para dez o total dos participantes.

A matéria PSDB à procura de um discurso de oposição traz à baila as reduzidas perspectivas de construção de um discurso de oposição por um partido que até o último momento apoiava o governo e cujo candidato somente pediu exoneração do cargo que ocupava de Secretário de Justiça e Cidadania do governo Cid dentro do prazo exigido para desincompatibilização dos que pretendiam candidatar-se a algum cargo nas eleições daquele ano. A convocação de Tasso frustrava os planos de Marcos Cals de uma reeleição considerada certa ao sexto mandato de deputado estadual:

"Da costela de Cid eis que surge o candidato tucano [...]. E Cals resistiu o quanto pode a concorrer a um cargo executivo, tendo repetido que preferia se manter aliado de Cid. Contudo, diante da ausência de nomes da confiança de Tasso Jereissati ele foi o escolhido. E imagino que isso tenha acontecido só depois de muita chiadeira". A bancada tucana ciente de que enfrentar frontalmente o governo seria no mínimo contraditório, preferiu destacar seu perfil competente e conciliador $(O$ POVO, 23/6/2010).

É emblemático o título da matéria publicada na edição do jornal em 25 de junho, "Para Tasso, Ciclo está cansado". Nela, o senador faz um misto de autocrítica e ensaio de ataque:

O senador Tasso Jereissati defendeu ontem durante entrevista coletiva em Fortaleza, o fim do controle do Ceará pelas famílias Jereissati e Ferreira Gomes que governam o Estado 
quase ininterruptamente há quase 24 anos. É um ciclo cansado, Ferreira Gomes e Jereissati, tá na hora de mudar ( $O$ POVO, 25/6/2010).

$O$ ataque foi sentido e retrucado pelo deputado estadual Ivo Gomes (PSB), irmão do governador e vice prefeito na $1^{\text {a }}$ gestão da prefeita Luizianne Lins (PT):

O Governo Cid Gomes não pertence ao ciclo político iniciado pelo ex-governador -e hoje senador- Tasso Jereissati, como afirmou o próprio tucano em tom de crítica. "O nosso governo é a inauguração de um novo ciclo no Estado do Ceará" (O POVO, 26/6/2010).

Após as querelas da pré-eleição, o cenário eleitoral que se apresentava no Ceará era de franco favoritismo das candidaturas de Dilma Rousseff (PT) para presidente, de Cid Gomes (PSB) para o Governo do estado e de Tasso Jereissati para o Senado. O teste de força entre os irmãos Ferreira Gomes e o tassismo seria travado na disputa ao Senado. Os acertos de última hora das cúpulas partidárias deixavam as bases eleitorais nos municípios perplexas e cautelosas sobre quem apoiar. De modo especial, os deputados e prefeitos, antes compromissados com as candidaturas de Tasso e Eunício ao Senado, tiveram que enfrentar o desconforto de não cumprir acordos estabelecidos. 0 deslocamento das bases eleitorais no interior do estado ao sabor dos ventos governistas promoveu uma rápida e vigorosa desestabilização do cenário eleitoral no qual a reeleição de Tasso Jereissati para o Senado era considerada certa.

\section{O que diziam as pesquisas eleitorais}

Dois institutos realizaram pesquisas de intenção de voto para o Senado no Ceará, IBOPE e O Povo/Datafolha, e ambos, embora com algumas diferenças nos percentuais, apresentaram resultados favoráveis a Tasso Jereissati, que aparecia sempre como o mais votado, seguido por Eunício Oliveira e José Pimentel. A tendência de queda de Tasso com transferência de votos para os dois candidatos da coligação governista foi detectada a partir de setembro, embora ele continuasse como o primeiro colocado. É o que analisamos a seguir.

\section{Pesquisas IBOPE}

A primeira pesquisa realizada na primeira semana de agosto reforçava a tese de que o ponto central da disputa era a segunda vaga para o Senado, tal a diferença entre Tasso e os demais concorrentes (Figura 1). Com 63\% de intenção de votos, Tasso suplantava a soma das intenções de votos de Eunício $(27 \%)$ e Pimentel $(25 \%)$. Vale ressaltar que a mesma pesquisa apontava que 


\section{DOSSIÊ OPINIÃO PÚBLICA, ELEIÇÕES E PARTICIPAÇÃO POLÍTICA NAS DEMOCRACIAS CONTEMPORÂNEAS}

$28 \%$ dos entrevistados citaram apenas o nome de um candidato e $26 \%$ declaravam-se indecisos. Outra observação relevante é que $65 \%$ dos eleitores de Tasso votavam em Cid Gomes para governador, candidato da principal coligação de oposição a ele, sugerindo que as bases eleitorais governistas relutavam em aceitar a dobradinha Eunício e Pimentel para o Senado.

Figura 1 - Primeira pesquisa IBOPE: Intenção de voto

(estimulada, até duas opções) - valores em (\%)

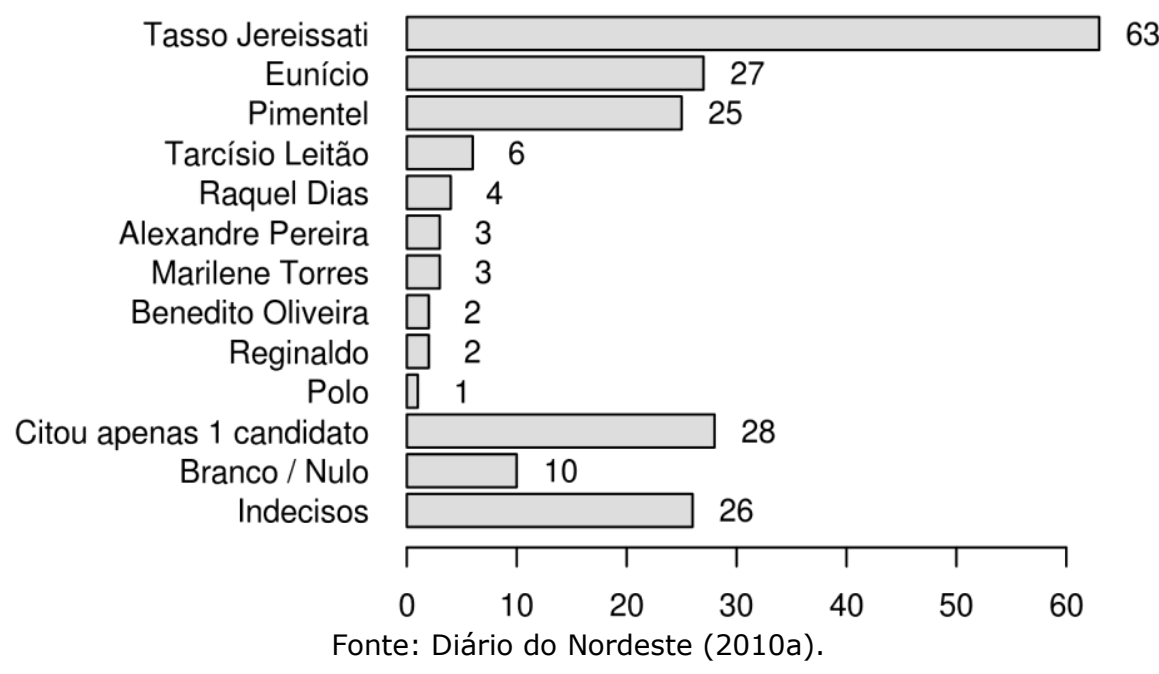

A segunda pesquisa IBOPE realizada entre 30 de agosto e $1^{\circ}$ de setembro não registrou grandes alterações nas posições dos três principais candidatos ao Senado (Figura 2). Tasso continuava na liderança com $63 \%$ das intenções de votos, Eunício Oliveira com $35 \%$ ocupava a segunda posição (8 pontos percentuais de crescimento), e Pimentel, a terceira posição com $31 \%$ (6 pontos de acréscimo). Comparando os dados das duas pesquisas, é possível inferir que se o crescimento do segundo e terceiro colocados não decorria da incorporação de votos de Tasso, era tributário da redução em $10 \%$ nos eleitores indecisos e dos com intenção em votar nulo. A soma dos votos de Eunício e Pimentel (66\%), entretanto, já ultrapassava o percentual de votos em Tasso (63\%). Segundo o relatório do IBOPE, $19 \%$ do eleitorado cearense mantinham-se até aquele momento indecisos em relação ao voto para o Senado; $7 \%$ votariam nulo ou branco e $33 \%$ dos eleitores citaram o nome de apenas um candidato quando poderiam votar em dois. 
Figura 2 - Segunda pesquisa IBOPE: Intenção de voto (estimulada, até duas opções) - (\%), publicada no Diário do Nordeste

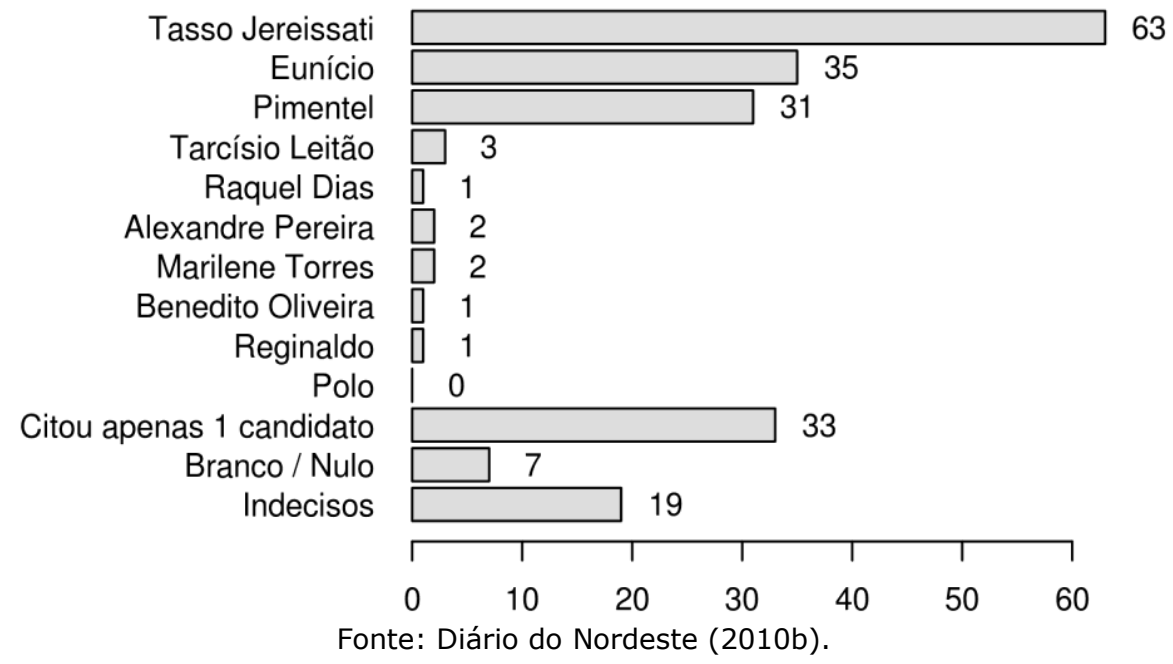

Na terceira pesquisa, realizada entre os dias 27 e 29 de setembro (DIÁRIO DO NORDESTE, 2010c), Tasso Jereissati continuava como primeiro colocado, com $50 \%$ das intenções de votos, registrando, porém, uma queda de 13 pontos em relação aos dados da pesquisa anterior. Em contrapartida, Eunício Oliveira, segundo colocado, cresceu 12 pontos, atingindo 47\%, seguido de perto por José Pimentel, que, com o acréscimo de 11 pontos, alcançou $42 \%$ nas intenções de voto. Os dados apresentados indicavam um rápido e forte declínio da candidatura de Tasso Jereissati ao Senado, abrindo a perspectiva de que poderia perder não apenas a liderança, mas até a segunda vaga do Senado.

\section{Pesquisas O Povo/Datafolha}

Na primeira pesquisa do O Povo/Datafolha, realizada entre 14 e 15 de julho, Tasso Jereissati apareceu como o candidato preferido por $59 \%$ dos eleitores; Eunício e Pimentel, empatados na segunda colocação com $24 \%$ das intenções de voto.

Era evidente a disputa acirrada entre os dois candidatos da coligação situacionista pelo segundo voto ao Senado. Os altos percentuais de eleitores que disseram não saber em quem votar para senador $(50 \%)$ e dos que optavam pelo voto em branco ou nulo (19\%), sugeriam que o cenário poderia ainda passar por grandes alterações.

A segunda pesquisa foi realizada nos dias 24 e 25 de agosto, após a 
primeira semana de horário eleitoral no rádio e na televisão. Embora Tasso continuasse liderando com $52 \%$ das intenções de voto, o candidato perdera sete pontos em relação à pesquisa anterior. Os dois candidatos da coligação situacionista cresceram: Eunício, sete pontos, ficou com 31\%, Pimentel, três pontos, atingiu $27 \%$ das intenções de voto.

Os dados da pesquisa apresentados na Tabela 1 oferecem um interessante registro sobre como os eleitores de Tasso definiam seus votos para a Presidência e Governo do estado: 61\% dos eleitores de Tasso votavam em Dilma (PT) para presidente e 53\% em Cid (PSB) para governador. Pode-se inferir por consequência que a liderança de Tasso na disputa para o Senado não estava desvinculada das escolhas dos eleitores para a Presidência e Governo estadual, ou seja, Tasso não era, até aquele momento, identificado como um candidato de oposição.

Tabela 1 - Intenção de voto para presidente e para governador segundo o voto para o Senado (\%)

\begin{tabular}{l|c|c|c}
\hline & Tasso & Eunício & Pimentel \\
\hline Dilma & 61 & 75 & 79 \\
\hline Serra & 25 & 16 & 9 \\
\hline Marina & 6 & 5 & 68 \\
\hline Cid & 53 & 67 & 18 \\
\hline Lúcio & 23 & 20 & 6 \\
\hline Cals & 14 & 8 & 5 \\
\hline
\end{tabular}

Fonte: O Povo/Datafolha, publicado no jornal O Povo em 28/8/2010.

Outra observação relevante é que $45 \%$ dos eleitores apontaram Tasso como primeira opção de voto para o Senado, enquanto o percentual de Eunício era de $14 \%$ e de Pimentel $12 \%$ (Figura 3). Em síntese, mais da metade dos eleitores escolhiam Tasso e mais um, confirmando que os dois candidatos da coligação situacionista disputavam entre si a segunda vaga, sem que se manifestasse qualquer posição "antitassista". A crise de infidelidade entre os candidatos da mesma coligação era nítida, o que suscitou uma mobilização do PT, nomeada de Setembro Vermelho, inicialmente encabeçada pela prefeita Luizianne Lins, depois abraçada fervorosamente pela direção nacional do partido e principalmente pelo próprio presidente Lula, que conclamava os eleitores para votar na dobradinha Eunício-Pimentel. 
Figura 3 - O Povo/Datafolha: Intenção de voto para o Senado (\%)

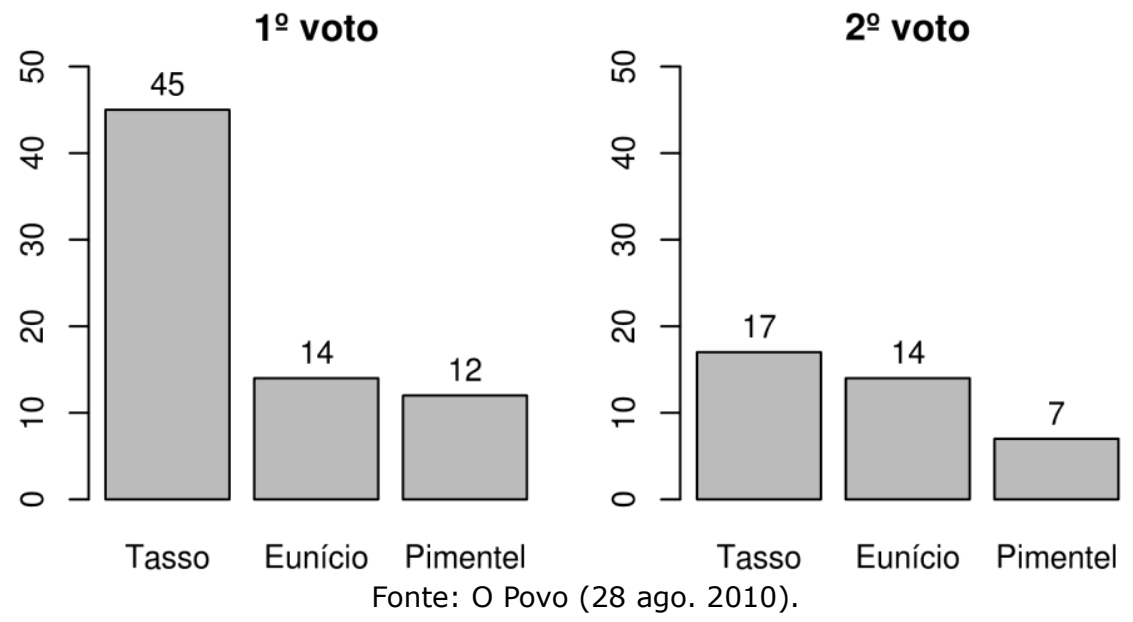

A tendência de queda de Tasso persistiu na $3^{a}$ pesquisa realizada pelo O Povo/Datafolha nos dias 13 e 14 de setembro, três semanas antes das eleições (Figura 4). Apesar do decréscimo de 4 pontos, ele ainda se mantinha na liderança com $48 \%$ das intenções de voto, 14 pontos de vantagem sobre Eunício que atingiu 34\%, e 17 pontos sobre Pimentel com $31 \%$.

Figura 4 - Evolução da intenção de voto para o Senado (\%). O Povo/Datafolha entrevistou 927 eleitores em 41 municípios cearenses.

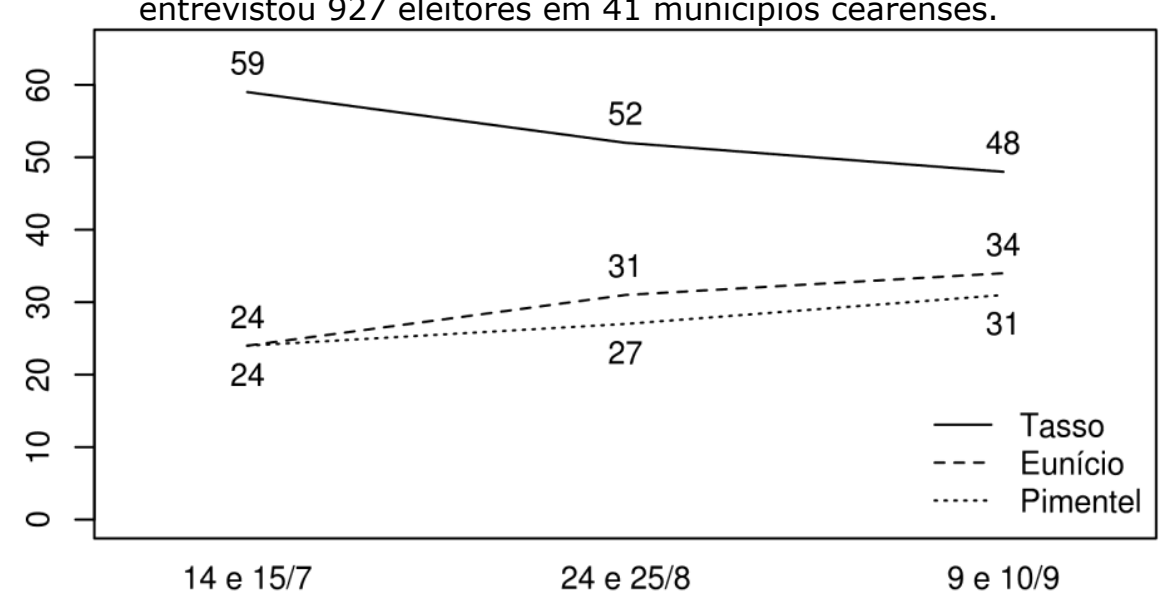

Fonte: O Povo (14 set. 2010).

O que tornava o resultado imprevisível era que o percentual de eleitores indecisos com a proximidade das eleições tinha aumentado, tendência inversa da esperada. Em julho, eram $16 \%$ os eleitores que não sabiam em quem votar para uma das duas vagas; em agosto o percentual 


\section{DOSSIÊ OPINIÃO PÚBLICA, ELEIÇÕES E PARTICIPAÇÃO POLÍTICA NAS DEMOCRACIAS CONTEMPORÂNEAS}

subiu para 20\%; e em setembro o índice atingiu $25 \%$; os que não sabiam em quem votar para nenhuma das duas vagas eram ainda mais numerosos, $42 \%$.

0 achado mais surpreendente desta pesquisa foi constatar que o tucano Tasso Jereissati apresentava desempenho melhor na capital e em municípios da Região Metropolitana de Fortaleza do que nos municípios do interior do estado. Apesar da intensa agenda de comícios e passeatas do senador Tasso Jereissati (PSDB) no interior do Ceará, a pesquisa $O$ Povo/Datafolha mostrou que ele perdera nove pontos percentuais nas intenções de voto da população do interior (inicialmente $52 \%$, decresceu para $48 \%$ em setembro).

Em eleições anteriores, eram justamente os votos obtidos nos municípios do interior do estado que sustentavam as vitórias do tassismo, contrabalançando as sucessivas derrotas na capital. Desta vez, foi exatamente em Fortaleza e nos municípios de seu entorno que Tasso alcançou $56 \%$ da preferência do eleitorado, cinco pontos a mais do que ele tinha no mês anterior, o que the garantiu permanecer como primeiro colocado na disputa para o Senado. Vale ressaltar que, na campanha de 2002, Tasso, candidato ao Senado, perdeu em Fortaleza, tendo sido eleito graças à maioria de 50 mil votos sobre o segundo colocado obtidos no interior do estado.

Nesta terceira pesquisa, Eunício e Pimentel também cresceram na região metropolitana de Fortaleza, porém em proporções menores do que Tasso: o primeiro de $31 \%$ para $36 \%$, e o segundo de $26 \%$ para $36 \%$.

Considerando que o percentual mais alto de indecisos estava no interior, era principalmente lá que os candidatos ao Senado tinham que buscar votos.

Na quarta e última pesquisa O Povo/Datafolha, realizada entre os dias 23 e 24 de setembro, Tasso, mesmo caindo mais quatro pontos, manteve-se em primeiro lugar com $44 \%$ das intenções de votos; Eunício subiu 4 pontos, atingindo $38 \%$, e Pimentel cresceu 5 pontos, chegando a 36\%.

O cenário aparentemente indefinido permitia uma leitura antecipada da derrota de Tasso. Considerando sua tendência constante de queda em todas as pesquisas anteriores, era pouco provável que fosse ele o beneficiário dos $17 \%$ de votos dos eleitores que declaravam ter candidato, mas admitiam mudar de voto; dos $35 \%$ dos eleitores indecisos quanto a um dos votos para o Senado, e dos $22 \%$ de indecisos sobre os dois votos. Os dados coletados sobre as opções mencionadas por aqueles que admitiam mudar de voto indicavam que a proposta de voto casado para o Senado em Eunício e Pimentel se firmara na cabeça dos eleitores.

i. Depois de começar com $65 \%$ entre o grupo de eleitores que têm de 16 a 24 anos, ele já havia caído para $45 \%$ na pesquisa realizada na segunda semana de setembro e na quarta e última pesquisa apresentou $37 \%$, seu pior percentual entre todas as faixas de idade.

ii. Em Fortaleza e região metropolitana, depois de ter alcançado, na pesquisa anterior, 13 pontos a mais que no interior ( $56 \%$ contra $43 \%$ ), na 
quarta pesquisa os índices ficaram tecnicamente empatados: $42 \%$ na capital e municípios próximos, contra $45 \%$ no resto do estado.

A análise do desempenho de Tasso ao longo das pesquisas ajuda a elucidar o aparente enigma de sua derrota: ele melhorou seu desempenho na capital, porém perdeu votos nos municípios do interior do Estado, onde estariam suas bases eleitorais cultivadas nas sucessivas gestões dos governos do PSDB e que supostamente teriam sido preservadas no governo de Cid Gomes que, mesmo filiado a outro partido (PSB), teve seu apoio na campanha eleitoral e no decorrer de seu primeiro mandato.

\section{Resultados das Eleições para o Senado no Ceará: a hipótese de voto casado nas disputas majoritárias} TRE-CE.

Nesta seção, analisaremos os resultados eleitorais divulgados pelo

Esperava-se que Tasso tivesse uma votação expressiva no interior e, de fato, a proporção dos eleitores que votou nele foi maior no interior. Como mostra a Tabela 2, Eunício também recebeu uma proporção maior dos votos dos eleitores do interior do que dos eleitores da região metropolitana, ocorrendo o contrário com Pimentel.

Tabela 2 - Número de votos de candidatos ao Senado segundo a localização

\begin{tabular}{l|c|c|c}
\hline & Tasso & Eunício & Pimentel \\
\hline Reg. Metrop. & $540.561(0,34 \%)$ & $859.000(0,54 \%)$ & $865.705(0,55 \%)$ \\
\hline Interior & $1.214 .006(0,39 \%)$ & $1.829 .833(0,59 \%)$ & $1.532 .146(0,49 \%)$ \\
\hline \multicolumn{4}{|c}{ Fonte: TRE-CE. }
\end{tabular}

A Tabela 3 mostra a proporção dos votos que cada um dos três candidatos mais votados para o Senado recebeu do total de votos recebidos pelos três, segundo o partido do candidato mais votado nas eleições para prefeito de 2008. A última coluna mostra o número de prefeituras de cada partido. Análises de regressão linear para cada um dos três candidatos revelam que somente no caso de Pimentel o impacto (negativo) do PSDB é significativo ao nível de $5 \%$. Para os demais candidatos, a variação na votação não tem relação significativa com o partido do prefeito do município. Ou seja, os eleitores dos municípios administrados pelo PSDB, embora tenham rejeitado Pimentel, não votaram em Tasso em maior proporção do que os eleitores dos demais municípios. A média das proporções municipais não é sempre um valor intermediário entre os valores apresentados na Tabela 2 porque os níveis de agregação dos dados são diferentes (2 regiões versus 184 municípios) e Tasso foi melhor votado nos municípios menores e Pimentel nos municípios mais populosos. 
Tabela 3 - Proporção dos votos recebidos pelos candidatos ao Senado em 2010 segundo o partido do candidato a prefeito mais votado nas eleições de 2008

\begin{tabular}{l|c|c|c|c}
\hline & Tasso & Eunício & Pimentel & $\mathbf{N}$ \\
\hline Outros & 0,41 & 0,58 & 0,49 & 13 \\
\hline PC do B & 0,38 & 0,59 & 0,44 & 5 \\
\hline PMDB & 0,38 & 0,58 & 0,50 & 33 \\
\hline PP & 0,47 & 0,53 & 0,53 & 8 \\
\hline PR & 0,43 & 0,59 & 0,40 & 9 \\
\hline PRB & 0,39 & 0,52 & 0,55 & 17 \\
\hline PSB & 0,37 & 0,58 & 0,52 & 23 \\
\hline PSDB & 0,44 & 0,61 & 0,41 & 56 \\
\hline PT & 0,34 & 0,58 & 0,53 & 15 \\
\hline Total & 0,38 & 0,57 & 0,41 & 5 \\
\hline
\end{tabular}

Fonte dos dados: TRE-CE.

Se recodificarmos a variável partido, tornando-a dicotômica ("PSDB" e "Outros"), o fato de um município ser ou não administrado por prefeito do PSDB passa a ser estatisticamente significativo para os três candidatos ao Senado. A Figura 5 ilustra a correlação existente entre as variáveis. Tasso e Eunício receberam, proporcionalmente, maior votação nos municípios administrados pelo PSDB e Pimentel teve maior votação nos municípios administrados por prefeitos de outros partidos.

Figura 5 - Proporção dos votos de candidatos ao Senado em 2010 segundo o partido do candidato mais votado para prefeito em 2008
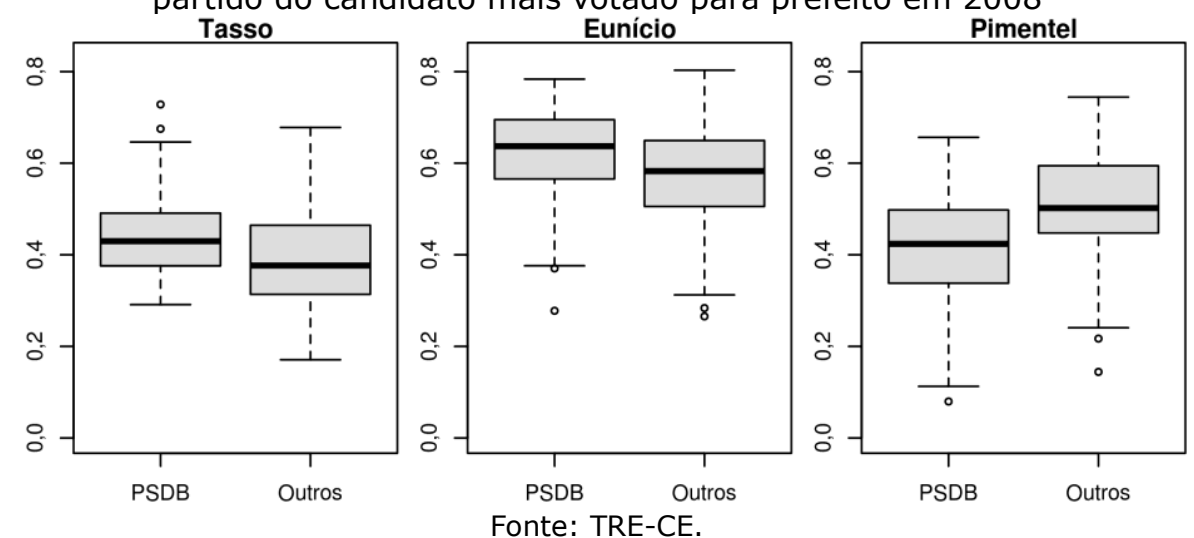

A Tabela 4 apresenta os coeficientes de Pearson para as correlações existentes entre a proporção dos votos dos municípios recebidos pelos três candidatos mais votados ao Senado em 2010 e a proporção recebida por deputados do PSDB em 2006 e 2010. A correlação mais fortemente positiva é entre a votação de Tasso e dos deputados federais do PSDB em 2006, maior 
até mesmo do que a correlação com os votos dos deputados estaduais e federais em 2010. As correlações entre os votos obtidos pelo candidato ao Senado do PT, José Pimentel, e os votos recebidos por candidatos a deputado estadual e federal em 2006 e em 2010 são negativas. Eunício Oliveira, do PMDB, não apresenta uma clara tendência de correlação positiva ou negativa com os votos recebidos pelos deputados do PSDB.

Tabela 4 - Correlação entre proporção de votos para deputados do PSDB (em 2006 e 2010) e proporção de votos para senador em 2010 nos municípios cearenses

\begin{tabular}{l|c|c|c}
\hline & Tasso & Eunício & Pimentel \\
\hline Dep. Est. 2006 & 0,14 & 0,14 & $-0,19$ \\
\hline Dep. Fed. 2006 & 0,14 & $-0,15$ & $-0,09$ \\
\hline Dep. Est. 2010 & 0,15 & 0,03 & $-0,09$ \\
\hline Dep. Fed. 2010 & 0,02 & $-0,01$ & $-0,12$ \\
\hline
\end{tabular}

Fonte: TRE-CE.

Comparando as tabelas 5 e 6 , percebemos que quase todos os coeficientes de Correlação de Pearson têm o mesmo sinal no interior e na região metropolitana, sendo, entretanto, mais fortes na região metropolitana. Há correlações negativas entre os votos de Tasso e Cid e de Tasso e Dilma. As correlações são inversas para Eunício e Pimentel, que receberam mais votos nas urnas em que Cid e Dilma também foram melhor votados. Nas duas tabelas, o total de eleitores utilizado para calcular as proporções corresponde à soma dos que votaram nos três candidatos mais votados de cada cargo.

Tabela 5 - Correlações: proporções de votos por urna em 2010 (interior)

\begin{tabular}{l|c|c|c}
\hline & Tasso & Eunício & Pimentel \\
\hline Dilma & $-0,25$ & 0,16 & 0,14 \\
\hline Marina & 0,06 & $-0,20$ & 0,09 \\
\hline Serra & 0,27 & $-0,06$ & $-0,24$ \\
\hline Cid & $-0,46$ & 0,32 & 0,24 \\
\hline Lúcio & 0,25 & $-0,25$ & $-0,07$ \\
\hline Cals & 0,28 & $-0,11$ & $-0,22$ \\
\hline
\end{tabular}

Fonte: TRE-CE.

Tabela 6 - Correlações: proporções de votos por urna em 2010 (região metropolitana)

\begin{tabular}{l|c|c|c}
\hline & Tasso & Eunício & Pimentel \\
\hline Dilma & $-0,73$ & 0,74 & 0,47 \\
\hline Marina & 0,48 & $-0,51$ & $-0,26$ \\
\hline Serra & 0,80 & $-0,75$ & $-0,58$ \\
\hline Cid & $-0,74$ & 0,73 & 0,48 \\
\hline Lúcio & 0,46 & $-0,49$ & $-0,25$ \\
\hline Cals & 0,64 & $-0,62$ & $-0,45$ \\
\hline
\end{tabular}

Fonte: TRE-CE. 


\section{DOSSIÊ OPINIÃO PÚBLICA, ELEIÇÕES E PARTICIPAÇÃO POLÍTICA NAS DEMOCRACIAS CONTEMPORÂNEAS}

\section{Resultados do survey pós-eleitoral: tentando decifrar a "cabeça dos eleitores"}

Nesta seção, serão apresentados os resultados do survey pós-eleitoral que conduzimos no estado do Ceará, tendo sido aplicados 809 questionários (362 na região metropolitana de Fortaleza e 447 em 11 municípios do interior do estado) entre os dias 22 e $28 / 11 / 2010^{2}$. Devido a restrições orçamentárias, não seria possível a realização de uma amostra probabilística ou mesmo o sorteio dos municípios a serem pesquisados. Foram selecionados alguns dos municípios mais populosos do estado e alguns municípios que, apesar de relativamente populosos, tiveram a votação para deputado estadual dominada por número reduzido de candidatos. Em Fortaleza, foram selecionados bairros de baixa renda, de classe média e de renda elevada. Para cada município (ou bairro de Fortaleza), foi estabelecida uma amostra de 40 pessoas a ser preenchida por quotas de sexo e faixa etária. Os resultados da pesquisa, portanto, não podem ser usados para descrever a população de eleitores, mas são valiosos para descobrir a existência de correlações entre diversas variáveis importantes. Não obstante, as limitações do processo de amostragem, nos dados coletados, o voto declarado pelos entrevistados se revelou razoavelmente próximo dos resultados eleitorais obtidos nas urnas para presidente e para senador, sendo, entretanto, bem maiores as divergências em relação aos votos para o Governo estadual, como mostra a Tabela 7.

Tabela 7 - Comparação dos votos declarados por entrevistados para os três candidatos mais votados de cada cargo e os resultados das urnas

\begin{tabular}{l|c|c|c|c|c}
\hline & Survey & $\%$ & Urnas & $\%$ & Dif. \% \\
\hline Dilma & 464 & 62,7 & 2.783 .451 & 67,0 & $-4,3$ \\
\hline Serra & 128 & 17,3 & 686.891 & 16,5 & 0,8 \\
\hline Marina & 148 & 20,0 & 686.770 & 16,5 & 3,5 \\
\hline Cid & 443 & 74,3 & 2.436 .940 & 63,0 & 11,3 \\
\hline Lúcio & 63 & 10,6 & 654.035 & 16,9 & $-6,3$ \\
\hline Cals & 90 & 15,1 & 775.852 & 20,1 & $-5,0$ \\
\hline Eunício & 287 & 37,9 & 2.688 .833 & 39,3 & $-1,4$ \\
\hline Pimentel & 295 & 38,9 & 2.397 .851 & 35,0 & 3,9 \\
\hline Tasso & 176 & 23,2 & 1.754 .567 & 25,6 & $-2,4$ \\
\hline
\end{tabular}

Fonte: TRE-CE e survey. O total de eleitores ou de entrevistados corresponde à soma dos que votaram (dados do TRE) ou declararam ter votado (survey) nos três candidatos mais votados de cada cargo.

\footnotetext{
2 questionário $\mathrm{e}$ os microdados do survey estão disponíveis em <http://www.lepem.ufc.br/dados/2010>.
} 
Dos 809 entrevistados, 427 lembraram com exatidão quais eram os cargos disputados nas eleições de 2010, ou seja, lembraram dos cinco cargos e não mencionaram nenhum cargo inválido. A Tabela 8 enumera quantas pessoas lembraram-se de cada cargo.

Tabela 8 - Número de vezes em que os cargos foram lembrados

\begin{tabular}{l|c|c}
\hline & N & $\%$ \\
\hline Presidente & 722 & 89,2 \\
\hline Governador & 607 & 75,0 \\
\hline Senador & 596 & 73,7 \\
\hline Deputado Federal & 631 & 78,0 \\
\hline Deputado Estadual & 644 & 79,6 \\
\hline Prefeito & 17 & 2,1 \\
\hline Vereador & 14 & 1,7 \\
\hline
\end{tabular}

Fonte: Survey.

Como mostra a Tabela 9, a maioria dos entrevistados que declarou ter votado em Tasso Jereissati para uma das vagas ao Senado votou somente nele. Já os eleitores dos outros dois candidatos mais votados, em sua maioria, votaram para as duas vagas. Os dados são semelhantes aos apresentados na Figura 3.

Tabela 9 - Frequência dos diferentes tipos de voto para Senado

\begin{tabular}{l|c|c|c}
\hline & Frequência & Percentual & $\%$ Válido \\
\hline Somente Tasso & 102 & 12,6 & 21,5 \\
\hline Somente Pimentel & 53 & 6,6 & 11,2 \\
\hline Somente Eunício & 35 & 4,3 & 7,4 \\
\hline Tasso e Pimentel & 32 & 4,0 & 6,8 \\
\hline Tasso e Eunício & 42 & 5,2 & 8,9 \\
\hline Pimentel e Eunício & 210 & 26,0 & 44,3 \\
\hline NA's & 335 & 41,4 & \\
\hline Total & 809 & 100,0 & 100,0 \\
\hline
\end{tabular}

Fonte: Survey.

Embora tenha sido o terceiro mais votado, a maioria dos entrevistados que votaram em Tasso o fizeram como primeira opção, como mostra a Tabela 10.

Tabela 10 - Voto para o Senado (primeira e segunda opções)

\begin{tabular}{l|c|c}
\hline & $\mathbf{1}^{\mathbf{a}}$ Opção & $\mathbf{2}^{\mathbf{a}}$ Opção \\
\hline Tasso & 148 & 29 \\
\hline Pimentel & 143 & 154 \\
\hline Eunício & 158 & 129 \\
\hline Outro/NR & 360 & 497 \\
\hline
\end{tabular}

Fonte: Survey. 
Como ilustra a Figura 6, um gráfico mosaico em que as áreas dos retângulos são proporcionais aos valores presentes nas células de uma tabela de contingência, os dados do survey confirmam as correlações encontradas com os dados agregados por seção eleitoral. Dos 697 entrevistados que informaram ter votado em Cid, Cals ou Lúcio para governador e em Tasso, Eunício e/ou Pimentel para senador, a grande maioria dos entrevistados que declarou ter votado em Cid Gomes também votou em Pimentel e Eunício. A maioria dos entrevistados que votou em Lúcio Alcântara ou Marcos Cals também votou em Tasso Jereissati e os eleitores de Marcos Cals rejeitaram Pimentel mais do que Eunício.

Figura 6 - Voto para senador versus voto para governador

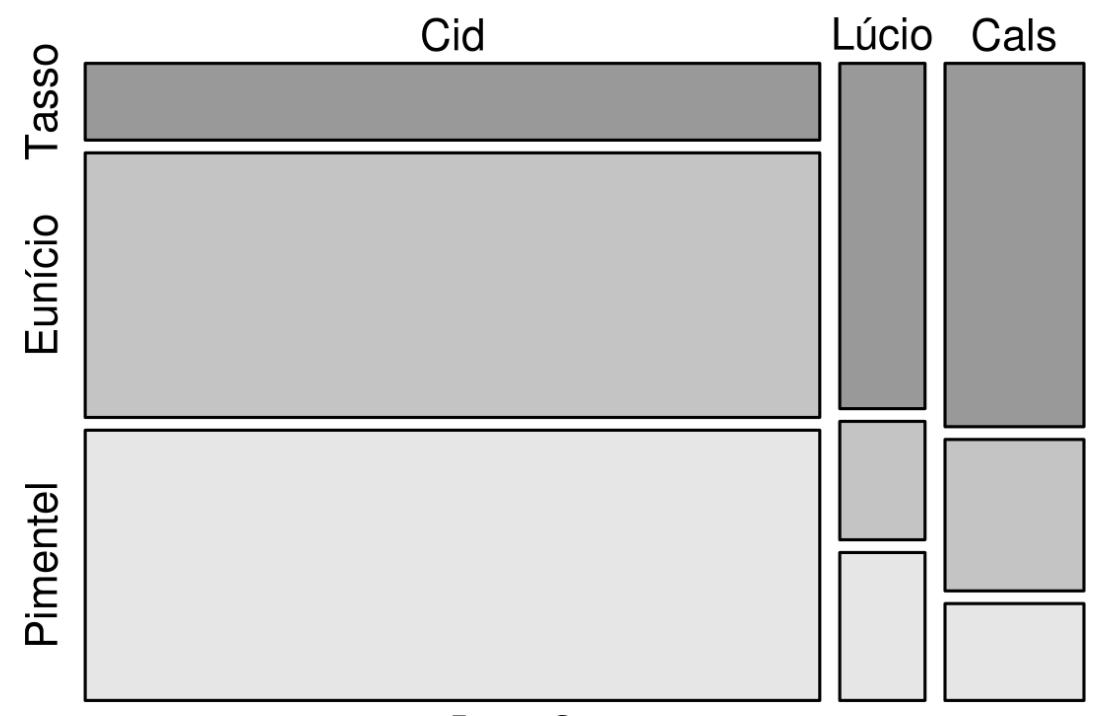

Fonte: Survey.

O quadro é semelhante na relação entre votos para presidente e para senador (Figura 7). Dos 743 entrevistados que votaram em Dilma, Marina ou Serra para presidente e em Tasso, Eunício e/ou Pimentel para senador, os eleitores de Dilma votaram, predominantemente, em Eunício e Pimentel e os eleitores de Serra, em Tasso. Os eleitores de Marina se dividiram uniformemente entre os três candidatos. 
Figura 7 - Voto para senador versus voto para presidente

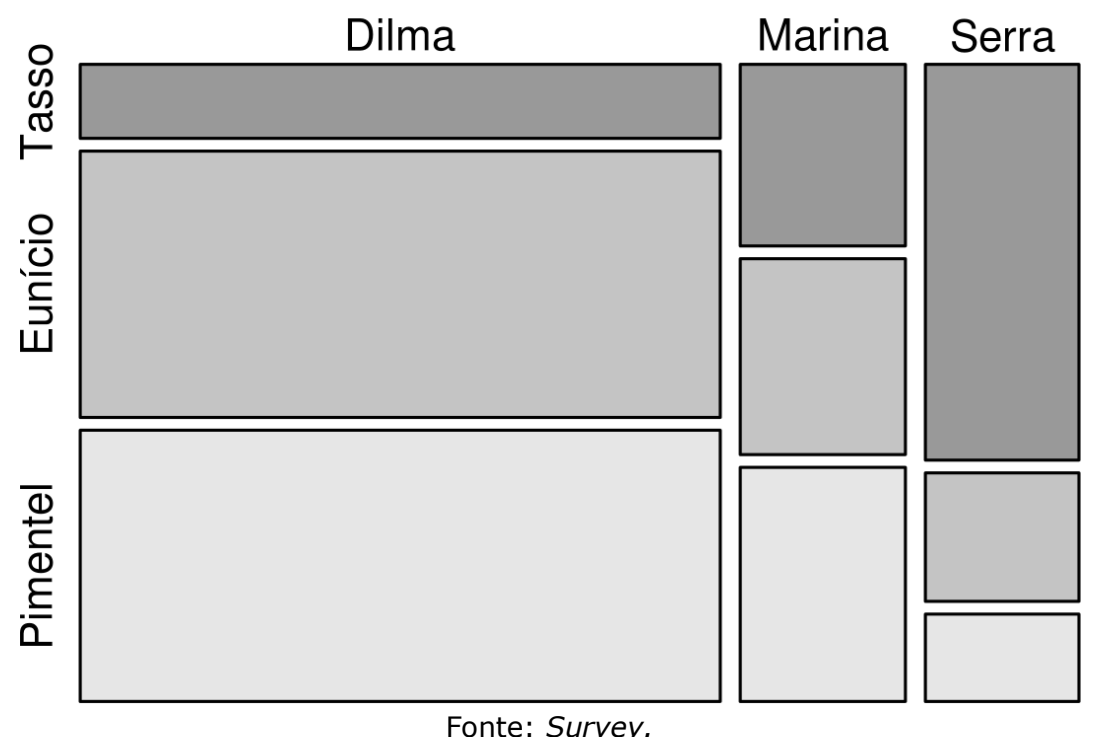

Como a amostra não foi probabilística, não é possível fazer uma estimativa da proporção dos votos de cada candidato ao Senado segundo o partido dos candidatos a deputado em que os entrevistados votaram. Mas, pelo menos relativamente ao total de votos declarados a deputados pelos entrevistados do survey, podemos afirmar que os eleitores de candidatos a deputado (estadual e federal) do PT votaram mais em Pimentel e Eunício; do PSDB, em Tasso e Eunício; do PMDB e PSB, em Eunício e Pimentel.

Embora Tasso Jereissati não tenha sido eleito, ele foi o candidato ao Senado mais lembrado pelos entrevistados. Como ilustra a Figura 8, os entrevistados lembraram mais dos candidatos a presidente. Cid Gomes foi mais lembrado do que os candidatos ao Senado, mas os outros dois candidatos ao Governo Estadual mais votados foram menos lembrados que Eunício Oliveira, um reflexo de como foi competitiva a disputa para o Senado. 
Figura 8 - Número de entrevistados que lembraram cada um dos candidatos mais votados para o Senado, o Governo e a Presidência

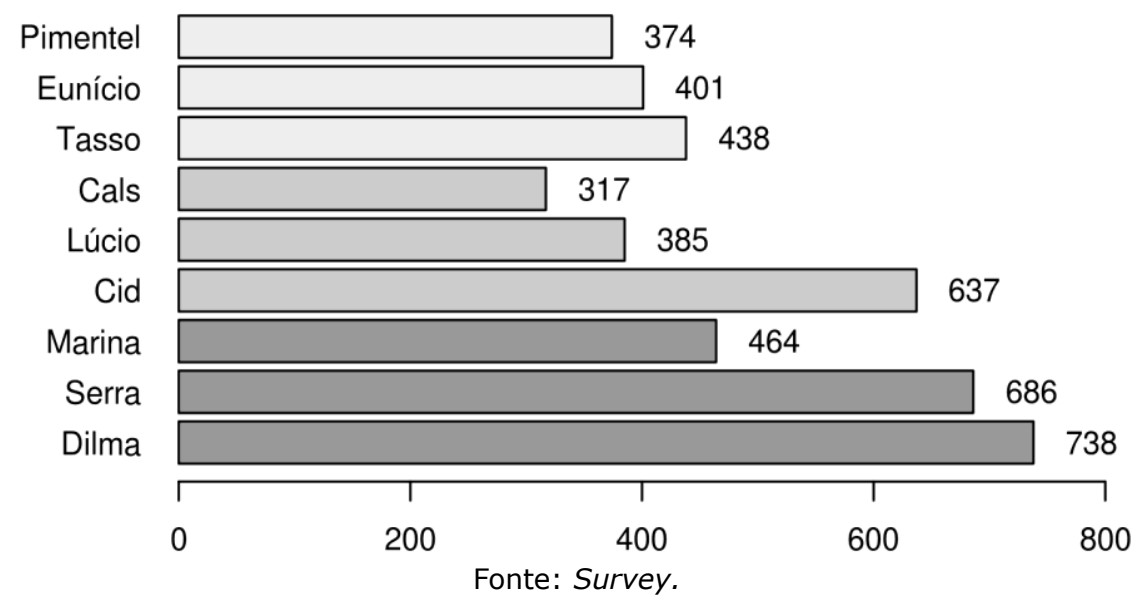

Os resultados do survey mostram que os eleitores de Tasso Jereissati avaliaram de forma menos positiva os governos de Cid Gomes e de Lula do que os eleitores dos demais candidatos ao Senado, como pode ser visto na Figura 9 ( $\mathrm{T}=$ somente Tasso, $\mathrm{P}=$ somente Pimentel, $\mathrm{E}=$ somente Eunício, TP = Tasso e Pimentel, $\mathrm{TE}=$ Tasso e Eunício, PE = Pimentel e Eunício). Os eleitores que, dos três candidatos mais votados, somente declararam ter votado em Tasso, foram os que avaliaram mais negativamente os governos Lula e Cid e os entrevistados que somente votaram em Eunício ou Pimentel foram os que melhor avaliaram os governos estadual e federal.

Figura 9 - Avaliação dos Governos Cid e Lula segundo o voto para o Senado

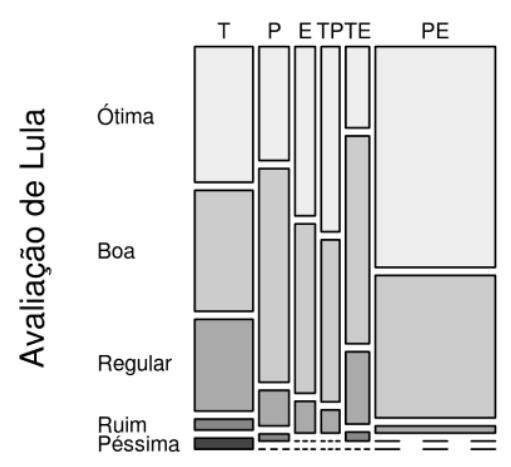

Voto para o Senado

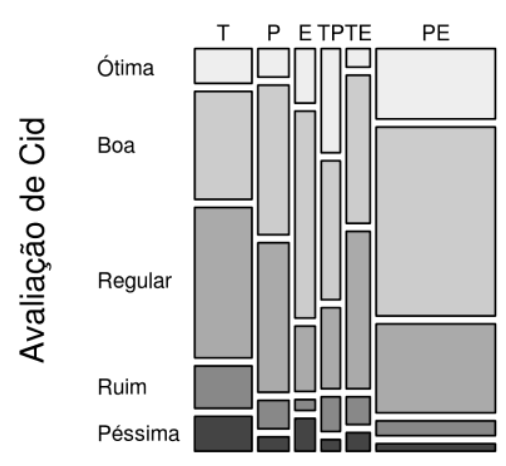

Voto para o Senado

Fonte: Survey. 
Como ilustra a Figura 10, a grande maioria dos entrevistados que declararam ter votado em Tasso disse tê-lo feito por considerarem que ele teve uma boa atuação como governador e senador, tendo feito muito pelo Ceará. Alguns poucos entrevistados mencionaram ter votado em Tasso para fazer oposição ao Governo. Os eleitores de Eunício e Pimentel declararam praticamente os mesmos motivos para terem votado nos dois candidatos. Muitos os consideravam bons candidatos, mas foi ainda maior o número dos entrevistados que afirmaram ter votado neles por serem da situação (aliados de Cid, de Lula, Dilma ou PT, ou, genericamente, do "governo"). Também foi considerável o número de entrevistados que mencionaram não votar em Tasso ou, mais enfaticamente, derrotar Tasso como motivo principal do voto em Eunício ou Pimentel.

Figura 10 - Por que votou em

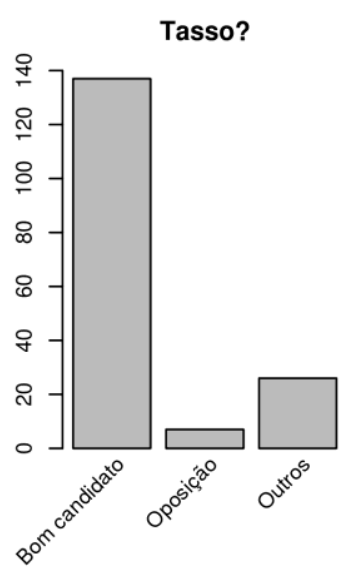

Eunício?

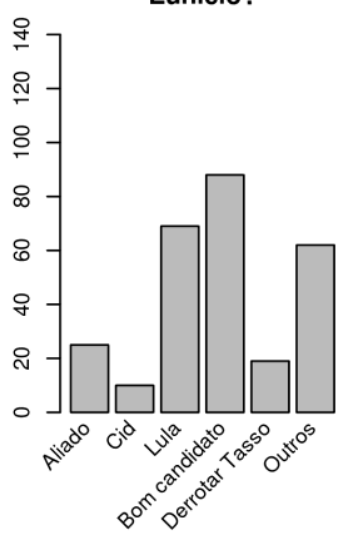

Fonte: Survey. para senador?

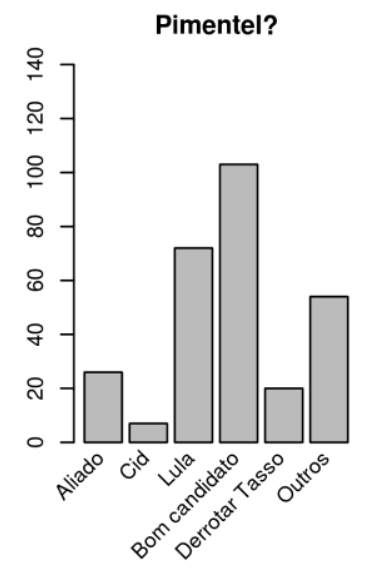

A Figura 11 ilustra o valor médio do índice de informação sobre política segundo o voto para o Senado. O índice foi calculado pela soma do número de cargos e números de candidatos a presidente, governador e senador lembrados, e o número de partidos políticos conhecidos. Os eleitores que votaram somente em Tasso e somente em Eunício são os que têm menor nível de informação. Os demais entrevistados têm todos, aproximadamente, o mesmo nível de informação. 


\section{DEMOCRACIAS CONTEMPORÂNEAS}

Figura 11 - Índice de informação sobre política segundo o voto para o Senado

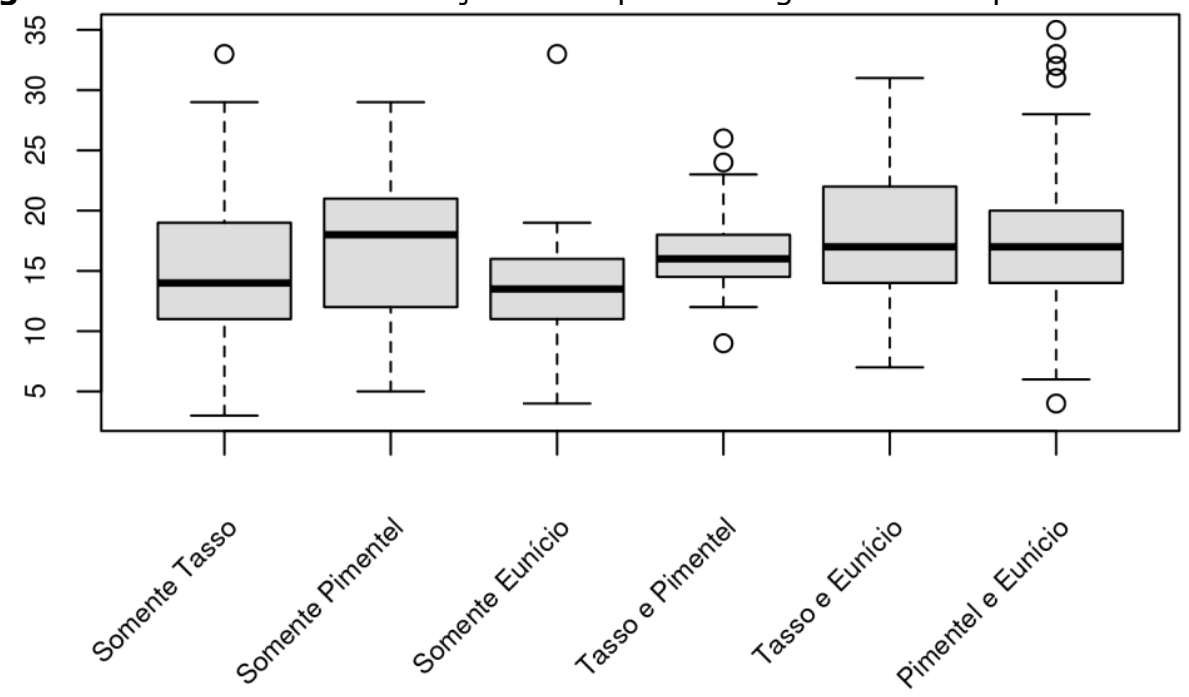

Fonte: Survey.

Resultado equivalente é obtido ao se fazer o cruzamento do voto do entrevistado com a frequência com que se informa sobre política em época não eleitoral (Figura 12). Como podemos ver, os entrevistados que mais acompanham as notícias sobre política em época que não é de campanha eleitoral são os eleitores de Pimentel (PT). Os eleitores de Tasso e, mais ainda, os de Eunício, raramente ou nunca se informam sobre política. O gráfico mosaico representa o cruzamento entre a frequência com que o entrevistado declarou acompanhar notícias sobre política em época não eleitoral e o tipo de voto para senador. 
Figura 12 - Interesse por política e voto para senador

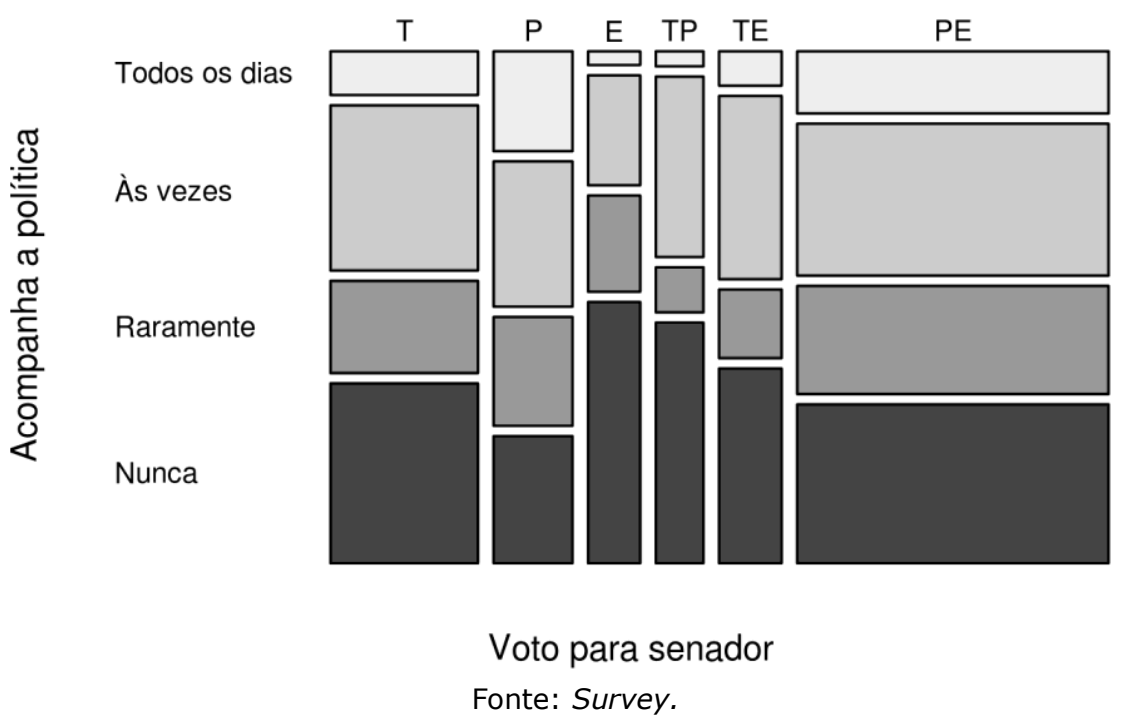

\section{Considerações finais}

Retomamos aqui a indagação principal posta no título deste artigo: como entender a rápida dissolução das bases eleitorais de Tasso, considerado no início da campanha de 2010 o franco favorito para ocupar a primeira vaga para o Senado?

Afinal quem integra as "bases eleitorais" e como elas são mobilizadas para votar em determinados candidatos?

A resposta mais evidente parece ser a de que na eleição em data coincidente para o Governo estadual e Senado os eleitores tendem a votar nos candidatos que são percebidos como estando no mesmo lado político: situação ou oposição.

Deste modo, enquanto não estava claro, para as "lideranças de base" (prefeitos municipais e deputados estaduais em especial) e para os eleitores dos municípios do interior do estado que declaravam a intenção de votar em Tasso Jereissati, que ele não era o candidato do presidente Lula e do governador Cid Gomes, sendo, portanto, candidato de oposição, ele permaneceu liderando as pesquisas como primeira opção de voto ao Senado.

Como exposto anteriormente, o deslocamento de votos foi tão rápido que nem as últimas rodadas de pesquisa eleitoral para o Senado, realizadas pelos institutos de pesquisa Datafolha e IBOPE, mesmo registrando acentuada 


\section{DOSSIÊ OPINIÃO PÚBLICA, ELEIÇÕES E PARTICIPAÇÃO POLÍTICA NAS DEMOCRACIAS CONTEMPORÂNEAS}

e contínua queda de Tasso, tiveram tempo suficiente para prognosticar sua derrota ${ }^{3}$.

A reviravolta aconteceu nas últimas semanas que antecederam as eleições de 3 de outubro, coincidindo com a reação do PT aos resultados das pesquisas até então divulgadas que indicavam o candidato do partido, José Pimentel, como terceiro colocado. O movimento chamado Setembro Vermelho arregimentou forças da militância cujo alvo era alimentar o voto anti-Tasso, apontado como a verdadeira oposição a ser derrotada no Ceará.

A derrota de Tasso constitui-se num fenômeno que possibilita interessantes reflexões sobre o que são as "bases eleitorais" situadas nos municípios do interior do estado e como elas são mantidas e funcionam em disputas eleitorais para diferentes cargos políticos. Reflexões que têm um caráter preliminar, exigindo um aporte teórico e empírico muito maior do que aqui podemos oferecer.

Os próprios conceitos de chefia política e "bases eleitorais" exigem uma revisão, já que se fundamentam nos termos de funcionamento da política tradicional do patrimonialismo oligárquico que pressupõem a combinação de força própria no controle duradouro do eleitorado localizado em seus "redutos" ou na terminologia mais atual, seus "colégios eleitorais". O processo de rápida urbanização e desmantelamento das relações de dependência pessoal e extra econômica nas relações de trabalho certamente minaram os fundamentos do patrimonialismo oligárquico. Seria indevido falar em "patronagem estatal" para entender como as lideranças locais atuam na intermediação dos governos com os eleitores que constituem em última instância as verdadeiras bases eleitorais? Como argumenta Borges "as relações entre clientes e chefes políticos na sociedade brasileira contemporânea têm um forte componente utilitário e instrumental, diferentemente dos laços de amizade e compadrio, de caráter não-racional, típicos do clientelismo tradicional" (2010, p. 186).

Para os cargos do executivo estadual, a tendência das lideranças das bases eleitorais interioranas (de modo especial prefeitos e deputados estaduais) é movimentar-se em direção ao polo situacionista, e somente tomar decisão diferente em campanhas cuja competitividade sugira, por um lado, o declínio do domínio político de determinado grupo ou partido político e, por outro, a ascensão de outras forças políticas (com possibilidade efetiva de alternância de poder).

Nas eleições de 2010, o que se tinha no Ceará era um alinhamento político das forças situacionistas nos níveis dos executivos federal

\footnotetext{
${ }^{3}$ Vale ressaltar que as pesquisas internas feitas pelo PSDB nos últimos dias que antecederam as eleições já indicavam que Tasso não seria eleito nem mesmo como segundo colocado. Uma semana após a divulgação dos resultados eleitorais pelo TRE, um militante do PSDB nos informou que essas pesquisas haviam sido realizadas.
} 
(Presidência), estadual (Governo) e municipal (Prefeitura da capital). A disputa para o Governo do estado só tinha um candidato forte: o próprio governador, cuja reeleição era certa.

O único fator complicador a ser resolvido era a ambígua posição de Tasso Jereissati que, por sua condição de aliado histórico dos irmãos Ferreira Gomes, suscitava dúvidas: ele é situação ou oposição? No decorrer das primeiras semanas da campanha, o governador Cid Gomes não direcionou qualquer ataque a Tasso, chegando inclusive a afirmar, em entrevista à imprensa, que o considerava o maior político vivo do Ceará, elogio que causou desconforto principalmente entre dirigentes e militantes do PT.

A intervenção esclarecedora e taxativa veio do alto e a galope. No dia 14 de setembro, foi realizada em Brasília uma "conversa" entre o presidente Lula, o governador Cid Gomes e os dois candidatos ao Senado de sua base aliada, Eunício e Pimentel. Da "conversa" foi extraído um trecho, a ser veiculado durante a propaganda eleitoral, em que o presidente Lula, em tom imperativo, mandava um recado aos seus eleitores:

Eu peço ao povo do Ceará, com o respeito e o carinho que eu tenho pelo povo do Ceará, que não permitam que a Dilma passe no Senado o que eu passei. [...] É muito importante votar no Eunício pro Senado e votar no Pimentel pro Senado. Quem votar no Pimentel vota no Eunício. Quem votar no Eunício vota no Pimentel. [...] Vote nos dois que são os melhores para ajudar a companheira Dilma a governar esse país e para ajudar o Cid a melhor governar o estado do Ceará.

Às palavras de Lula, Cid acrescentou:

A eleição do Eunício e do Pimentel, do Pimentel e do Eunício, tem que ser casadinha. Tem que ser uma eleição votando nos dois porque os dois estão afinados com o projeto de Ceará, os dois estão afinados com o projeto de Brasil e os dois jogam no mesmo time $[\ldots]$

E Lula concluiu:

E lembre-se: você pode dar dois votos pro Senado. Quem votar em um vota no outro. Quem votar no outro vota no outro e não precisa votar em mais ninguém. Só nos dois.

$\mathrm{Na}$ forma de spots, a cena foi ao ar repetidas vezes nos intervalos comerciais da programação normal da $\mathrm{TV}^{4}$. O efeito deste fato na campanha

${ }^{4}$ Até o momento em que este texto era escrito, a cena encontrava-se disponível na internet no

REVISTA DEBATES, Porto Alegre, v. 5, n. 2, p. 145-180, jul.-dez. 2011. 


\section{DOSSIÊ OPINIÃO PÚBLICA, ELEIÇÕES E PARTICIPAÇÃO POLÍTICA NAS DEMOCRACIAS CONTEMPORÂNEAS}

de Tasso, como analisado neste artigo, foi devastador. Os resultados das urnas não deixaram dúvidas, ultrapassando em muito todas as previsões das pesquisas: Tasso foi o terceiro colocado com uma diferença de 934 mil votos do primeiro, e 643 mil votos do segundo, José Pimentel. A rapidez no deslocamento de votos sugere que, na verdade, Tasso já não era detentor de bases políticas próprias no interior do estado; elas já gravitavam em torno de Cid Gomes, candidato à reeleição.

O situacionismo não é uma tendência nova na política cearense e nacional. $O$ que se pode considerar como novidade na fase da última redemocratização é sua acentuação decorrente do instituto da reeleição dos governantes, ampliando o horizonte temporal de sua permanência no poder.

Nosso interesse em comparar o comportamento dos eleitores da capital e do interior remete-se à tese, recorrente nos estudos políticos no Brasil, e mais ainda no Nordeste, de que há entre eles diferenças relevantes ${ }^{5}$. A mais importante seria a de que os votos dos eleitores do interior seriam "mediados" pelas lideranças dos prefeitos e de parlamentares (deputados estaduais) que concentram sua área de influência em determinados municípios, constituindo uma espécie de "circunscrição eleitoral informal" (VIEIRA, 2011). Sem negar a validade da perspectiva de análise aberta pela "geografia do voto" (N. CARVALHO, 2003), pretendemos entender a natureza das relações que se estabelecem entre governantes e as "bases eleitorais". Os dados desta e de outras pesquisas recentes sugerem que a linha de comando dos votos é descendente, ou seja, parte dos governadores do estado e atinge deputados estaduais e prefeitos que gravitam em torno do poder na busca pragmática de prover recursos para alimentar suas próprias bases eleitorais (PESSOA JR., 2011). De modo especial, deputados estaduais e prefeitos de municípios menores são destituídos de força eleitoral própria que torne viável a decisão de manter-se na oposição sem sofrer danos vigorosos em suas carreiras políticas.

Outro aspecto que favorece a tendência situacionista atual é que os governantes dependem menos do "trabalho político" de mediação exercido por deputados e prefeitos na medida em que podem estabelecer ligações diretas com as bases eleitorais (BEZERRA, 1999). A ampliação dos programas federais e estaduais com recursos a serem aplicados nos municípios permite que os governadores se apresentem aos eleitores como responsáveis pelas benfeitorias instaladas nos municípios, sem necessariamente dividir bônus com os políticos locais considerados de oposição. A publicidade institucional midiática e as práticas dos "governos itinerantes" favorecem a imagem de

seguinte endereço: <http://www.youtube.com/watch?v=XioafcBccXk>.

${ }^{5}$ Ver textos clássicos da sociologia brasileira tais como os de Faoro (1989) e Queiroz (1976) e outros textos que discutem as novas formas de clientelismo político no Brasil tais como os de $\mathrm{J}$. M. de Carvalho (2004), Gondim (1998) e Andrade (2004). 
gestão dos governantes aproximando-os de forma direta das bases eleitorais nos municípios. Alteram-se, por consequência, as condições de estabelecimento da conexão eleitoral definida em termos genéricos por Monteiro como a

[...] habilidade de os eleitores se disporem a não renovar o mandato eletivo do político (ou sequer elegê-lo para um primeiro mandato ou não votar em candidatos que o político possa patrocinar), caso o eleitor não apoie o desempenho pregresso desse político ou não acredite na realização da plataforma de provisão de políticas anunciada pelo candidato (MONTEIRO, 2010, p. 535).

Para Monteiro, a conexão eleitoral se vincula à responsabilização eleitoral e desse modo:

[...] a ameaça de não vencer a próxima eleição gera incentivos para que o representante eleito atue no interesse de seu reduto eleitoral, independentemente de qualquer objetivo privado de políticas públicas que esse detentor de mandato eletivo possa ter (2010, p. 535).

Compreende-se assim que, na eleição de 2010, era Tasso quem dependia do apoio do governador Cid Gomes, esperando que sua lealdade pairasse acima das diferenças partidárias no plano nacional e estadual. A fragilidade de sua posição revelou-se na rápida erosão de um suposto capital político acumulado durante as duas décadas em que esteve no comando da política do estado.

Dados do survey pós eleitoral evidenciam que dos 176 entrevistados que declararam ter votado em Tasso Jereissati para uma das vagas ao Senado, 32 também votaram em José Pimentel e 42 em Eunício Oliveira. Em contraste, dos 295 entrevistados que declararam ter votado em Pimentel, 210 também votaram em Eunício. Ou seja, predominou a regra do "voto casado" nos candidatos da situação. E o que é mais sintomático, os eleitores dos municípios administrados pelo PSDB, embora tenham rejeitado Pimentel, não votaram em Tasso em maior proporção do que os eleitores dos demais municípios.

Embora Tasso tenha sido o terceiro mais votado, a maioria dos entrevistados que declararam ter votado nele o fizeram como primeira opção, o que sugere que o fato dele não ter indicado desde o início da campanha um outro candidato para o segundo voto ao Senado pode ter contribuído, ainda que secundariamente, para ampliar sua derrota. Sua campanha foi planejada e realizada de olho na primeira colocação e não na segunda. Os eleitores de Tasso votaram nele não apenas por considerá-lo um bom candidato (Figura 9), mas o melhor candidato: votaram nele predominantemente os eleitores 


\section{DOSSIÊ OPINIÃO PÚBLICA, ELEIÇÕES E PARTICIPAÇÃO POLÍTICA NAS DEMOCRACIAS CONTEMPORÂNEAS}

que o tinham como primeira opção de voto (Tabela 10). Apesar disso, muitos dos seus eleitores também votaram em Pimentel ou Eunício (Tabela 9). Se Tasso tivesse apoiado claramente um candidato para a segunda vaga ao Senado, poderia, pelo menos entre seus eleitores mais fiéis, ter evitado o voto em Eunício ou Pimentel.

Em entrevista realizada em julho de 2011 por João Paulo Gomes ${ }^{6}$, Tasso Jereissati, ao ser indagado se a não indicação, já no início da campanha, do nome de um candidato para o segundo voto ao Senado o teria prejudicado, responde: "Olha, pode ter sido um erro, mas na minha opinião, não foi o fundamental. Eu acho que foi um erro não se ocupar o segundo voto."

Na mesma entrevista, a resposta de Tasso explicando sua derrota é bastante longa e certamente contaminada por sua visão amarga e pessimista sobre as dificuldades de ocupar um lugar de oposição depois de por tanto tempo ter sido o grande mandatário da política cearense:

Você tem várias coisas, tudo conta. Primeiro, que não se pode negar, um gigantesco prestígio do Lula. Todo esse prestígio foi colocado aqui em peso, $100 \%$ na campanha. Não sei se você lembra, mas na campanha, eu era candidato contra o Lula e não contra os dois. Todo dia na aparição, todos os programas de televisão do lado do governo, aparecia o Lula pedindo o voto e pedindo o não voto, foi assim uma coisa maciça. Entrou com telefones, com telemarketing, um negócio também maciço e isso atrás de um prestígio dele que não dá para se negar, para se esconder. [...] Depois você tem a Máquina do Governo Estadual, a quantidade de recursos gigantesca que era impossível de se enfrentar, a quantidade de recursos que entraram, e agora tão aparecendo de onde é que vinham tantos recursos. Tanto é que era uma soma de dinheiro que qualquer outro partido não poderia competir. $\mathrm{E}$ também o governo do estado estava bem avaliado.

O acirramento do situacionismo se expressa também nas alianças eleitorais com participação de um número de partidos cada vez maior e nas coalizões partidárias que, de tão extensas, beiram a unanimidade. Em nome da "governabilidade" todos os acordos partidários são justificados (LOPES, 2011). O conceito de "presidencialismo de coalizão" (ABRANCHES, 1988), cunhado por cientistas políticos para caracterizar a dinâmica política brasileira, aproxima-se perigosamente do mero adesismo. Os frequentes escândalos envolvendo personagens de quase todos os partidos em casos de desvio de recursos públicos sinalizam para os riscos de que os ideais da democracia

\footnotetext{
${ }^{6}$ Graduando em ciências sociais pela Universidade Federal do Ceará, bolsista de iniciação
} científica do CNpq e pesquisador do LEPEM. 
representativa se afastem cada vez mais dos ideais normativos da política como forma de organização da vida coletiva para a realização do bem comum.

\section{Agradecimentos}

Somos gratos, pelos vários comentários e sugestões de melhorias, aos pareceristas anônimos da Revista Debates e a Vitor Peixoto, debatedor da sessão do GT sobre Comportamento Político da ANPOCS 2011, no qual apresentamos este trabalho. É de nossa inteira responsabilidade falhas remanescentes.

Rejane Maria Vasconcelos Accioly de Carvalho é Doutora em Sociologia pela Universidade Federal do Ceará, Professora do PPG em Sociologia e do Departamento de Ciências Sociais da mesma universidade, vinculada ao Laboratório de Estudos sobre Política, Eleições e Mídia.

E-mail: rejanecarvalho@terra.com.br

Jakson Alves de Aquino é Doutor em Sociologia e Política pela Universidade Federal de Minas Gerais, Professor do PPG em Sociologia e do Departamento de Ciências Sociais da Universidade Federal do Ceará, vinculado ao Laboratório de Estudos sobre Política, Eleições e Mídia.

E-mail: jaa@ufc.br

\section{Referências}

ABRANCHES, Sérgio. Presidencialismo de coalizão: o dilema institucional brasileiro. Dados, Rio de Janeiro, v. 31, n. 1, p. 5-34, 1988.

ANDRADE, Luis Aureliano Gama de. O município na política brasileira: revisitando Coronelismo, enxada e voto. In: AVELAR, Lúcia; CINTRA, Antônio Octávio (Orgs.). Sistema político brasileiro: uma introdução. Rio de Janeiro/ São Paulo: Fundação Konrad-Adenauer-Stiftung/Fundação Unesp, 2004. p. 243-256.

BEZERRA, Marcos Otávio. Em nome das bases. Rio de Janeiro: Relume Dumará, 1999.

BORGES, André. Já não se fazem máquinas política eleitorais com antigamente: competição vertical e mudança eleitoral nos estados brasileiros. Revista de Sociologia e Política, Curitiba, v. 18, n. 35, p. 167-188, fev. 2010.

CARNEIRO, Leandro Piquet; ALMEIDA, Maria Hermínia Tavares de. Definindo a arena política local: sistemas partidários municipais na federação brasileira. 
Dados, Rio de Janeiro, v. 51, n. 2, p. 403-432, 2008.

CARVALHO, José Murilo de. Fundamentos da política e da sociedade brasileiras. In: CARVALHO, José Murilo de; CINTRA, Antônio Octavio (Orgs.). Sistema político brasileiro: uma introdução. Rio de Janeiro/São Paulo: Fundação Konrad Adenauer-Stiftung/Fundação Unesp, 2004. p. 19-31.

CARVALHO, Nelson Rojas de. E no início eram as bases: geografia do voto e comportamento legislativo no Brasil. Rio de Janeiro: Revan, 2003.

CARVALHO, Rejane Vasconcelos Accioly. A nova burguesia cearense: discurso regionalista e luta pela hegemonia. In: ENCONTRO DE CIÊNCIAS SOCIAIS DO NORDESTE, 5., 1990, Recife. Anais. Recife: Fundação Joaquim Nabuco, v. II, 1991.

- Transição democrática brasileira e padrão publicitário midiático da política. Campinas/Fortaleza: Pontes/UFC, 1999.

- Imagem marca e continuísmo político: a era Tasso no Ceará. In: BATISTA, José Élcio; PINHEIRO, Joceny de Deus (Orgs.). Olhares Contemporâneos: cenas do mundo em discussão na universidade. Fortaleza: Demócrito Rocha, 2001. p. 195-209.

Virgílio, Adauto e César Cals: a política como arte da chefia. In: PARENTE, Josênio; ARRUDA, José Maria (Orgs.). A Era Jereissati no Ceará: modernidade e mito. Fortaleza: Demócrito Rocha, 2002. p. 25-43.

- Política de imagem e competitividade eleitoral: a disputa pela prefeitura de Fortaleza em 2000. In: __. A produção da política em campanhas eleitorais. Campinas/Fortaleza: Pontes/Programa de Pós Graduação em Sociologia e UFC, 2003. p. 91-125.

. Como se faz e desfaz um fenômeno eleitoral: o caso Roseana. In: RUBIM, Antonio Albino Canelas (Org.). Eleições presidenciais no Brasil: ensaios sobre mídia, cultura e política. São Paulo: Hacker/CULT, 2004. p. 220249.

O Ceará na Década de 1980: atores políticos e processos sociais. Campinas: Pontes Editores/Programa de Pós Graduação em Sociologia da UFC, 2009.

DIÁRIO DO NORDESTE. Cid Gomes hoje seria reeleito. Diário do Nordeste, Fortaleza, 3 ago. 2010a. Disponível em:

<http://diariodonordeste.globo.com/materia.asp?codigo=825678>. 
Acesso em: 3 ago. 2010.

. Hoje, Cid estaria reeleito. Diário do Nordeste, Fortaleza, 3 set. 2010b. Disponível em:

<http://diariodonordeste.globo.com/materia.asp?codigo $=844670>$.

Acesso em: 3 set. 2010.

. Tasso lidera para o Senado. Diário do Nordeste, Fortaleza, 1 out. 2010c. Disponível em:

<http://diariodonordeste.globo.com/m/materia. asp?codigo $=860442>$. Acesso em: 1 out. 2010.

FAORO, Raymundo. Os donos do poder. São Paulo: Globo, 1989.

GONDIM, Linda Maria de Pontes. Clientelismo e modernidade: os "governos das mudanças" no Ceará (1987-1994). Ijuí: Ed. Unijuí, 1998.

LEMENHE, Maria Auxiliadora de Abreu. Imagens e símbolos de uma disputa política. In: LEMENHE, Maria Auxiliadora de Abreu; CARVALHO, Rejane Vasconcelos Accioly de (Orgs.). Política, cultura e processos eleitorais. Ed. Konrad Adenauer. Fortaleza, 2006. p. 171-189.

LOPES, Monalisa Soares. Em nome da governabilidade: uma análise do discurso político brasileiro (2002-2010). 2011. 156 f. Dissertação (Mestrado em Sociologia), Universidade Federal do Ceará, Fortaleza, 2011.

MELO, Carlos Ranulfo Felix de. Eleições presidenciais, jogos aninhados e sistema partidário no Brasil. Revista Brasileira de Ciência Política, Brasília, n. 4., p. 13-41, jul.-dez. 2010.

MONTEIRO, Jorge Vianna. A Conjuntura das escolhas públicas. Revista de Administração Pública, Rio de Janeiro, v. 44, n. 2, p. 533-544, mar.-abr. 2010.

O POVO. Tucanos querem Tasso para Governador. O Povo, Fortaleza, 12 jan. 2010, p. 22.

p. 18.

.Ciro insiste em candidatura própria. O Povo, Fortaleza, 06 fev. 2010, . Governador quer, tucanos também, mas resistência persiste. O Povo, Fortaleza, 01 maio 2010, p. 20.

- Tasso teme estar sendo cozinhando por Cid e convoca reunião para decidir rumos eleitorais. O Povo, Fortaleza, 08 jun. 2010, p. 25. 
DOSSIÊ OPINIÃO PÚBLICA, ELEIÇÕES E PARTICIPAÇÃO POLÍTICA NAS DEMOCRACIAS CONTEMPORÂNEAS

. De aliado a adversário - Sem resposta de Cid, PSDB anuncia disputa ao governo. O Povo, Fortaleza, 11 jun. 2010, p. 20.

. PSDB à procura de um discurso de oposição. O Povo, Fortaleza, 23 jun. 2010, p. 19.

. Para Tasso, Ciclo está cansado. O Povo, Fortaleza, 25 jun. 2010, p.

22.

jun. 2010, p. 19.

. Ivo nega relação com o projeto mudancista. O Povo, Fortaleza, 26 . Tasso cai; Eunício e Pimentel sobem mas ainda não ameaçam. $O$ Povo, Fortaleza, 28 ago. 2010, p. 24.

PESSOA JR., José Raulino Chaves. Entre as bases e o governo: trajetória política de deputados estaduais da região dos Inhamuns (1970-2010). 2011. 210 f. Dissertação (Mestrado em Sociologia), Universidade Federal do Ceará, Fortaleza, [2011].

QUEIROZ, Maria Isaura Pereira de. O mandonismo local na vida política brasileira. São Paulo: Alfa-Omega, 1976.

TRE-CE. Tribunal Regional Eleitoral do Ceará. Eleições. Disponível em: <http://www.tre-ce.gov.br/tre/eleicoes>. Acesso em: 05 dez. 2010.

VIEIRA, Márcia Paula Chaves. Poder Legislativo no Ceará: geografia do voto e ação política na Assembleia Legislativa. Dissertação (Mestrado em Sociologia). 2011. 160 f. Universidade Federal do Ceará, Fortaleza, 2011.

Texto recebido em 22/08/2011. Aprovado em 07/12/2011. 